\title{
Tuberculosis and poverty: the contribution of patient costs in sub-Saharan Africa - a systematic review
}

\author{
Devra M Barter ${ }^{\text {* }}$, Stephen O Agboola, Megan B Murray ${ }^{2}$ and Till Bärnighausen ${ }^{1,3}$
}

\begin{abstract}
Background: Tuberculosis (TB) is known to disproportionately affect the most economically disadvantaged strata of society. Many studies have assessed the association between poverty and TB, but only a few have assessed the direct financial burden TB treatment and care can place on households. Patient costs can be particularly burdensome for TB-affected households in sub-Saharan Africa where poverty levels are high; these costs include the direct costs of medical and non-medical expenditures and the indirect costs of time utilizing healthcare or lost wages. In order to comprehensively assess the existing evidence on the costs that TB patients incur, we undertook a systematic review of the literature.

Methods: PubMed, EMBASE, Science Citation Index, Social Science Citation Index, EconLit, Dissertation Abstracts, CINAHL, and Sociological Abstracts databases were searched, and 5,114 articles were identified. Articles were included in the final review if they contained a quantitative measure of direct or indirect patient costs for treatment or care for pulmonary TB in sub-Saharan Africa and were published from January 1, 1994 to Dec 31, 2010. Cost data were extracted from each study and converted to 2010 international dollars (I\$).

Results: Thirty articles met all of the inclusion criteria. Twenty-one studies reported both direct and indirect costs; eight studies reported only direct costs; and one study reported only indirect costs. Depending on type of costs, costs varied from less than $\$ 1$ to almost $\$ 600$ or from a small fraction of mean monthly income for average annual income earners to over 10 times average annual income for income earners in the income-poorest 20\% of the population. Out of the eleven types of TB patient costs identified in this review, the costs for hospitalization, medication, transportation, and care in the private sector were largest.

Conclusion: TB patients and households in sub-Saharan Africa often incurred high costs when utilizing TB treatment and care, both within and outside of Directly Observed Therapy Short-course (DOTS) programs. For many households, TB treatment and care-related costs were considered to be catastrophic because the patient costs incurred commonly amounted to $10 \%$ or more of per capita incomes in the countries where the primary studies included in this review were conducted. Our results suggest that policies to decrease direct and indirect TB patient costs are urgently needed to prevent poverty due to TB treatment and care for those affected by the disease.
\end{abstract}

Keywords: Tuberculosis, Economic impact, Out-of-pocket costs, Africa

\footnotetext{
* Correspondence: dbarter@post.harvard.edu

${ }^{1}$ Department of Global Health and Population, Harvard School of Public

Health, 677 Huntington Avenue, Boston, MA 02115, USA

Full list of author information is available at the end of the article
} 


\section{Background}

In 2009, tuberculosis (TB) was the world's 7th leading cause of death, resulting in 1.7 million deaths worldwide, more than 9.4 million new infections and 14 million prevalent cases [1]. TB is often known as "a disease of the poor" because the burden of TB follows a strong socioeconomic gradient both between and within countries, and also within the poorest communities of countries with high TB incidence [2]. Some studies have shown a strong association between poverty and TB and have demonstrated that poor and vulnerable groups are at an increased risk of TB infection, have a higher prevalence of disease, have worse outcomes (including mortality), and display worse TB care-seeking behaviors [3-8]. Risk factors for these TB-related outcomes include structures, behaviors and other diseases commonly associated with poverty - overcrowded living or working conditions, poor nutrition, smoking, alcoholism, diabetes, exposure to indoor air pollution and HIV [2,7-10].

It is also well-known that $\mathrm{TB}$ can contribute to poverty by reducing patients' physical strength and ability to work [8,11-13]. However, another pathway through which TB can affect households' economic situation, the costs patients incur when utilizing TB care, has been less studied. These costs include both direct out-of-pocket costs incurred when seeking treatment and care and the indirect, or time costs, associated with utilizing healthcare. While most countries with high ТB burden provide free sputum smear microscopy for patients with suspected pulmonary $\mathrm{TB}$, more than half of these 22 countries charge for other TB-related diagnostic tests such as radiography, sputum culture, and drugsusceptibility testing [14]. Under Directly Observed Therapy Short-course (DOTS) programs, all high burden TB countries provide free first line anti-TB medication, but many patients purchase anti-TB drugs in private pharmacies (some without prescriptions), which can be costly $[14,15]$. In high TB burden countries, $60 \%$ of overall health expenditure is in the private sector, and a large proportion of these expenditures are paid out-of-pocket by patients [14].

A number of previous studies have documented the downstream consequences of the direct and indirect costs that TB patients incur. More than $50 \%$ of $\mathrm{TB}$ patients have been reported to experience financial difficulties due to TB [16], and these costs can be "catastrophic" in that they amount to more than $10 \%$ of patients' or households' annual income [17-19]. TB patient costs have been shown to lead to reduced food consumption, diversion of resources from other types of healthcare, taking children out of school, and borrowing or selling assets [17,19-21]. Furthermore, financial constraints have been shown to predict non-adherence to TB medication [16]. In general, the World Health
Organization (WHO) estimates that 100 million people every year fall into poverty from paying for health services [22].

One earlier review reports on the overall costs TBpatients in Africa face during the pre- and postdiagnosis phases of TB treatment and care as well as coping mechanisms for catastrophic costs [23]. In this study, we expand on this previous assessment by broadening the evidence base on TB patient costs in subSaharan Africa through screening of additional databases and broadening the study design inclusion criteria, systematically identifying the particular types of TB patient costs (both direct and indirect), systematically reviewing the evidence on the cost quantities for each cost type, and providing benchmarks for the magnitude of cost burdens on TB patients and households.

\section{Methods}

\section{Data sources and search strategies}

We used eight electronic databases to identify papers reporting on patient costs for TB care in sub-Saharan Africa available by January 3-4, 2011: PubMed, Embase, Science Citation Index, Social Science Citation Index, EconLit, Dissertation Abstracts, Cumulative Index to Nursing and Allied Health Literature (CINAHL), and Sociological Abstracts. Each search strategy comprised a Boolean operator of "and" with two elements: tuberculosis and cost/economic aspects. For the PubMed search, $\mathrm{MeSH}$ and "all fields" terms comprising tuberculosis and OR fields for cost estimates such as "employment," "out of pocket," "patient costs" and MeSH terms for "costs and cost analysis" were used. Similar search strategies were employed for the other 7 databases (see Additional file 1 for the precise search algorithms for each database). Each database was searched from the earliest referenced publication date through January 1, 2011. Studies were included regardless of language. Two reviewers independently screened articles identified from the initial search of the databases by title and/or abstract.

To identify additional articles, conference abstracts written in English from 1994-2010 from the International Union Against Tuberculosis and Lung Disease (IUATLD) annual conference were searched. Furthermore, we performed a secondary search of reference lists of articles identified through the database search, including both the primary studies included in our synthesis and review studies.

Articles were considered for inclusion if they contained a quantitative measure of a direct or indirect patient-incurred cost (including time costs) relating to TB treatment or care for adult pulmonary tuberculosis. Following Rajeswari et al. [24] and Jackson et al. [25] we defined costs as follows: Direct costs included both 
medical expenditures (such as consultation fees or costs of medication or diagnostic tests) and non-medical expenditures (such as money spent on travel, lodging, and food for both patients and caregivers). Indirect costs were defined as time costs associated with utilizing healthcare, or time costs converted into monetary units based on loss of wages for both patients and caregivers or decreased earning ability [26].

We excluded the following articles: i) published before 1994 when DOTS was officially launched as a framework for a TB control strategy recommended by the WHO [27]; ii) not taking place in Sub-Saharan Africa; iii) not pertaining to $\mathrm{TB}$; iv) not involving human subjects; v) on MDR-TB, HIV/TB co-infection, latent or pediatric $\mathrm{TB}$; vi) focusing solely on diagnostic tests, screening tests, or vaccinations; vii ) not containing any primary data on cost estimates or economic analysis; or viii) not relating to individual patient costs.

Articles were assessed for study quality. In particular, we examined the studies to ensure that we included only those in our final review that had clearly defined objectives, clearly defined study populations, and a quantitative measure of patient-costs. Additionally, articles were categorized by study type and whether costs were incurred pre- or post-diagnosis. We adhered to the PRISMA guidelines [28].

\section{Data extraction and analysis}

In addition to study-specific variables (authors, study type, year, location, setting, period of observation, population under study, and study objectives), the two reviewers extracted patient-borne quantitative direct and indirect cost measurements. We extracted only costs measured empirically in the reviewed studies. Costs that were extrapolated or projected in mathematical models were not included in the analysis. Data were categorized into costs related to health insurance, prepayment, consultation or provider fees, hospitalization, medication, and diagnostic test costs, traditional healer and food costs, travel costs, time costs, reported impact on income, reported direct, indirect, and total costs, caregiver costs and catastrophic costs.

To compare costs expressed in different currencies and measured in different years, we converted all cost 180 estimates into 2010 international dollars (I\$). We rounded all cost estimates to the nearest integer except for costs less than 1I\$, which we rounded to the second decimal place. For costs that were presented in US\$, costs were first converted to respective local currency units using OANDA currency conversions [29] based on exchange rates at the commencement of the study period. For studies that did not specify the year or period of currency estimates, January $1^{\text {st }}$ of the beginning of the study year was used as a standard conversion date except for one study in Botswana [30], for which conversion rates were only available beginning November 1, 1993 instead of January 1, 1993, and for one study in Uganda [31], for which conversion rates were available beginning January 1, 1996 instead of January 1, 1992. Next, local currency units were adjusted to 2010 rates using the International Monetary Fund's database on average consumer price inflation over time [32]. Finally, costs were adjusted to 2010 international dollars based on the World Bank's purchasing power parity (PPP) conversion factors (in local currency units per international dollar) [33].

To compare costs across studies, we report travel costs as single visit costs and hospitalization costs over the entire treatment period. To provide a benchmark for the magnitude of cost burdens of TB care on patients, we expressed the expenditures as percentage of per-capita annual (or monthly) GDP (in I\$) of the country and in the year when the study, which generated the cost estimates, was conducted. The per-capita GDP figures are taken from the World Development Indicators published by the World Bank [33]. Per-capita GDP, i.e., the average income, is one benchmark that is meaningful to understand and commonly used for such purposes, and we thus use it here. However, since TB is a disease that predominantly affects poorer populations, we also express the cost estimates as a percentage of an alternative income benchmark-the percapita income of the income-poorest $20 \%$ of the population, calculated according to the following equation:

Total GDP $*$ Income share of the income-poorest $20 \%$ of the population Total population size $* 0.2$

We chose these two income benchmarks, rather than study population-specific incomes, because very few of the studies included in our review reported the study population income. We also report whether the patient costs of TB treatment are "catastrophic" for the person of average income or the person of average income amongst the income-poorest $20 \%$ of the population, classifying costs as "catastrophic" when they were at least $10 \%$ of average annual income for the respective population. While definitions of catastrophic expenditures commonly relate to household income, [18,34-37] we chose to use $10 \%$ of annual individual income as a benchmark for catastrophic costs because for most studies we lack householdlevel income data as well as the household-level TB data that would be necessary to judge whether the financial burdens of TB care and treatment is "catastrophic" or not. Without the latter data, householdlevel income data is not an appropriate indicator since TB tends to cluster in households [38-40]. 


\section{Results}

5,114 articles were identified from the initial search of the eight databases. After excluding 1,112 duplicate articles, 1,510 were excluded because they did not include TB as a major subject heading, 777 did not include cost estimates, 632 were published before 1994, 427 focused solely on diagnostic tests, screening tests or vaccinations, 331 did not include patient cost estimates, and 95 did not involve human subjects. Reviewing the full text of the remaining 230 articles, we found that 55 did not include a quantitative cost measurement; 14 were reviews, commentaries, letters or editorials that did not include primary data; 7 were on pediatric TB, 13 on MDR-TB, 6 on latent TB, 4 on HIV/TB, 105 studies did not take place in sub-Saharan Africa; and 2 studies were by the same authors and included the same data (leading to the exclusion of 1 of the 2 studies). This selection process resulted in 25 relevant studies; 5 additional relevant publications were identified through the search of the conference database and reference lists, so that a total of 30 articles were included in the final synthesis of our review (see Figure 1).

Table 1 describes each of the 30 studies in terms of their study populations, main objectives, types of cost estimates, and time period in which costs were incurred (pre- vs. post-diagnosis). Eight studies reported direct costs, one study reported indirect costs, and twenty-one studies reported both indirect and direct costs. Table 2 describes the cost categories, including definitions for each cost type, whether the costs are considered direct or indirect, whether the cost are incurred pre- or postdiagnosis, the number of studies reporting a particular cost type, and the cost range and median among all studies reporting the cost type.

\section{Health insurance, prepayment fees, consultation} and private provider fees

Two studies reported health insurance fees that ranged from $\mathbf{I} \$ 2$ to $\mathbf{I} \$ 3$ in Zambia [41,59], and four studies reported consultation or prepayment fees that ranged from I\$2 in Ethiopia [55] and Botswana [30] to I\$7 in Zambia [58]. Patients who did not seek care from the public sector paid fees for care in the private sector. Four studies noted such fees for private services, which ranged from I\$24 (median I\$10) in Zambia [58] to I\$141 in Uganda [47] (see Table 3). Additionally, one study from Uganda reported the practice of "tipping" healthcare providers in the range of I $\$ 5-\mathrm{I} \$ 40$ [46].

\section{Hospitalization, medication, and diagnostic tests costs}

Ten studies reported hospitalization expenses. Costs ranged from I\$4 in Uganda [61] to over I\$530 in Kenya [60]. Some patients were required to pay hospital admission fees. Patients in Freetown, Sierra Leone paid an average of I\$1 at a missionary hospital and I\$47 at a government hospital, which included the cost of food [52]. Five studies reported medication costs that ranged from I\$20 in Uganda [46] to I\$548 in Nigeria [42] (see Table 4). Moreover, one study from Kenya reported that patients paid I $\$ 46$ monthly for syringes and needles for streptomycin treatment (not including streptomycin itself) [43]. Three studies reported diagnostic test costs other than sputum smears which ranged from I\$7 for chest radiographs [41] to I $\$ 10$ for examination, laboratory, and X-ray fees in Tanzania [68].

\section{Traditional healer and food costs}

Five studies reported that patients paid between $I \$ 3$ in Malawi [44] to I\$563 in Uganda [47] to see traditional healers, and four studies reported the cost of food, which ranged from I\$4 (interquartile range (IQR) I\$1I\$7) in Zambia to I\$36 in Ethiopia and Zambia (median I\$19) for "special food" [41,48,58] (see Table 5).

\section{Travel costs}

Eighteen studies reported travel costs for patients, families, or guardians for single visits or for multiple visits during treatment. Costs ranged from less than I\$1 in South Africa for a single health clinic visit $[51,63]$ to I\$70 in Ethiopia for pretreatment transportation costs [65] (see Table 6). Travel time also varied from $48 \mathrm{~min}$ utes in Cape Town, South Africa [63] and Kampala, Uganda [46] to almost 70 hours in Ethiopia under a health-facility based DOTS system for a single visit [48]. One study from Zambia distinguished between pre and post diagnosis travel costs: pre-diagnosis travel costs were I\$3 (IQR I\$1 - I\$) while post-diagnosis costs were I\$11 (IQR I\$4- I\$29) [41]. In addition to travel costs, one study reported accommodation costs (in Ethiopia) [55].

\section{Time costs}

Twenty-one studies reported time costs. Clinic visit wait time varied from 30 minutes in Limpopo Province, South Africa [49] to 111 minutes in Kampala, Uganda [46]. One study from Uganda reported that patients spent on average 22 minutes for a volunteer-supervised outpatient DOTS visit or I\$0.23 (95\% CI I\$0.00- I $\$ 0.42$ ) in lost income, and an average of 110 minutes for a health-facility visit, or I\$1 (95\% CI I\$1- I\$2) in lost income [61].

Lost work time varied by treatment system. For hospitalized patients in South Africa, each hospital day led to an average of 402 minutes of lost work time (I\$7 in lost income) compared to 128 minutes (I\$2) for a health clinic visit, 50 minutes (I\$0.85) for a DOTS visit with a community health worker chosen as a treatment supervisor, and 4 minutes (I\$0.51) with another type of health worker chosen as a supervisor [51]. In Malawi patients lost an average of 22 workdays resulting in an average 


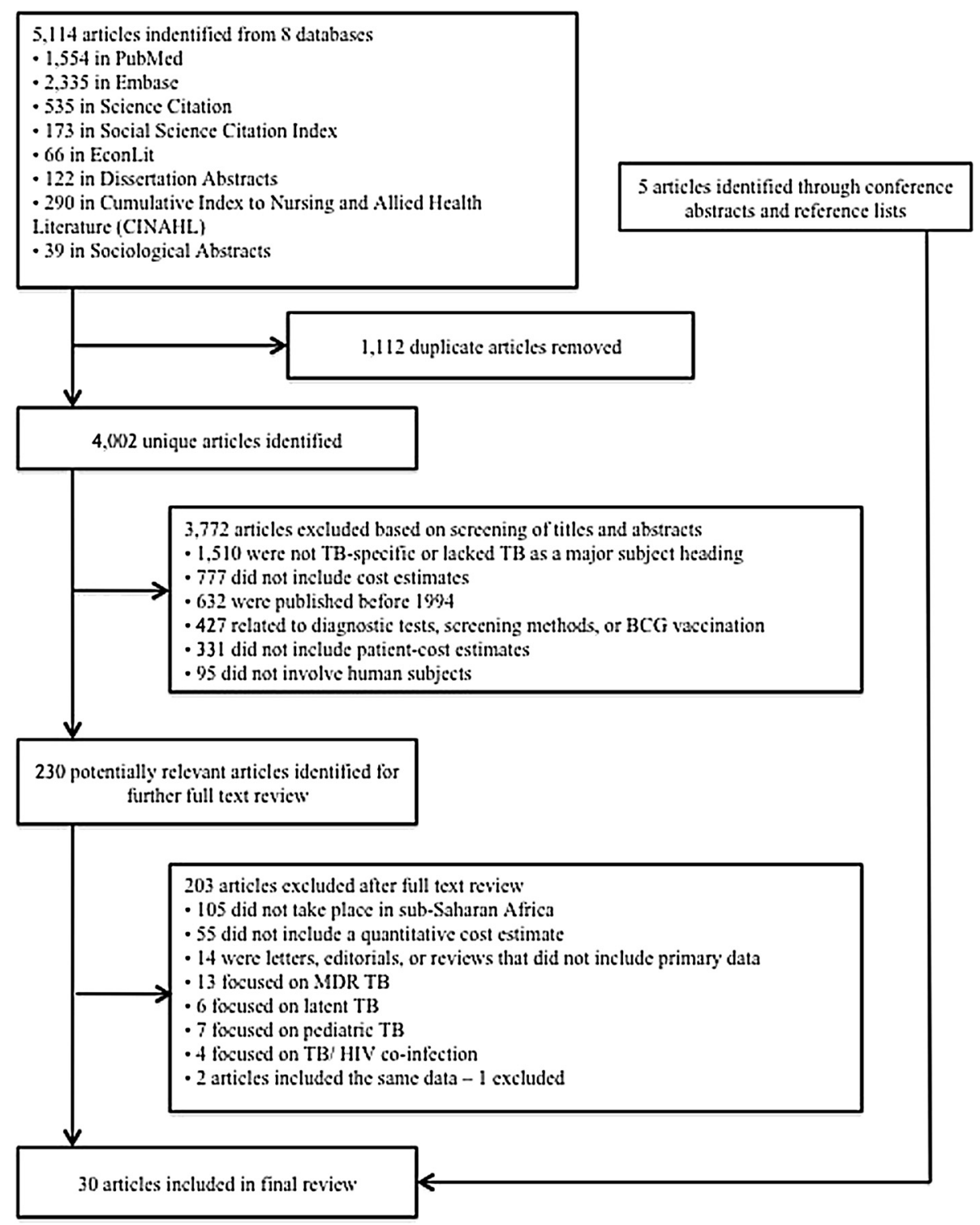

Figure 1 Flowchart of the systematic review.

income loss of I\$68 [54]. Two studies in Zambia found that patients missed an average of 18 workdays before being diagnosed with TB [58] and 48 days of missed work in total [59]. Foregone earnings reported for any type of care-seeking activity ranged from I\$3 in South Africa [63] to I\$169 in Tanzania [68].

\section{Reported impact on income}

Five studies surveyed patients on their salaries and reported the impact of TB patient costs on household incomes $[41,55,58,59,65]$; one study used average household income estimates from an external source to calculate the impact of TB patient costs on household incomes [54]. In Malawi, patients spent between 129\% and 244\% of their mean monthly income (MMI) on TB diagnosis [54].
In Zambia, patients spent $16 \%$ of their MMI on transportation costs and $66 \%$ of their MMI on food [59]. Direct medical expenditures ranged from between 10\% of MMI for men and 132\% of MMI for women in Zambia [41] to $31 \%$ for all patients in Ethiopia [55], while non-medical expenditures ranged from $42 \%$ in Ethiopia [55] to $55 \%$ of MMI in Zambia [58]. In Ethiopia, 48\% and 35\% of annual household income was lost due to TB treatment and pretreatment costs, respectively [65].

\section{Reported direct, indirect and total costs}

Eight studies reported aggregated overall direct costs, and six studies reported aggregated overall indirect costs incurred by patients (although authors defined direct and indirect costs differently). Reported direct costs 
Table 1 Summary of Studies

\begin{tabular}{|c|c|c|c|c|c|c|}
\hline Author (Year) & Country & Type of study & Population under study & Primary objectives & Types of costs reported & $\begin{array}{l}\text { Time period of costs } \\
\text { (Pre vs. post diagnosis) }\end{array}$ \\
\hline Aspler, et al. (1998) [41] & Zambia & Cross-sectional & $\begin{array}{l}103 \text { patients aged } \geqslant 18 \text { years } \\
\text { with active or extra-pulmonary } \\
\text { TB who had been on } \\
\text { treatment for } 6-10 \text { weeks }\end{array}$ & $\begin{array}{l}\text { To estimate TB patient } \\
\text { costs for treatment and } \\
\text { diagnosis and cost } \\
\text { determinants }\end{array}$ & $\begin{array}{l}\text { Pre-diagnosis, treatment, } \\
\text { time, travel, medication, } \\
\text { consultation, hospitalization, } \\
\text { food, health insurance, and } \\
\text { diagnostic test costs }\end{array}$ & Both \\
\hline Awofeso, N. (1998) [42] & Nigeria & Prospective cohort & $\begin{array}{l}2144 \text { symptomatic } \\
\text { smear-positive patients } \\
\text { in two study periods }\end{array}$ & $\begin{array}{l}\text { To discuss the implications } \\
\text { of pre-payment versus } \\
\text { free medication therapy } \\
\text { on treatment and case- } \\
\text { finding of TB patients }\end{array}$ & Medication costs & Post-diagnosis \\
\hline Bevan, E. (1997) [43] & Kenya & Unknown & Unknown & $\begin{array}{l}\text { Letter to describe other } \\
\text { costs associated with DOTS }\end{array}$ & $\begin{array}{l}\text { Daily inpatient care, } \\
\text { travel, and other } \\
\text { medical expenses }\end{array}$ & Post-diagnosis \\
\hline Brouwer, et al. (1998) [44] & Malawi & Cross-sectional & $\begin{array}{l}89 \text { smear-positive pulmonary } \\
\text { TB patients admitted to } \\
\text { Queen Elizabeth Central } \\
\text { Hospital }\end{array}$ & $\begin{array}{l}\text { To investigate how TB } \\
\text { patients utilize traditional } \\
\text { healers and traditional } \\
\text { medicine in their care- } \\
\text { seeking behaviors }\end{array}$ & $\begin{array}{l}\text { Total fixed and variable } \\
\text { costs, time, and } \\
\text { traditional healer costs }\end{array}$ & Pre-diagnosis \\
\hline Cambanis, et al. (2005) [45] & Ethiopia & Cross-sectional & $\begin{array}{l}243 \text { patients undergoing } \\
\text { sputum examination for } \\
\text { TB diagnosis }\end{array}$ & $\begin{array}{l}\text { To assess factors related } \\
\text { to patient delay in } \\
\text { presenting to health } \\
\text { services for the diagnosis } \\
\text { of TB }\end{array}$ & Time and travel costs & Pre-diagnosis \\
\hline Chard, S. (2001) [46] & Uganda & Cross-sectional & $\begin{array}{l}89 \text { female patients aged } \geqslant \\
18 \text { years identified from } \\
\text { a TB clinic }\end{array}$ & $\begin{array}{l}\text { To examine treatment } \\
\text { seeking, health beliefs, } \\
\text { and social networks of } \\
\text { female Ugandan TB patients }\end{array}$ & $\begin{array}{l}\text { Time, travel, medication, } \\
\text { traditional healers, and } \\
\text { costs for "tipping" } \\
\text { healthcare providers }\end{array}$ & Both \\
\hline Chard, S. (2009) [47] & Uganda & Cross-sectional & $\begin{array}{l}65 \text { women aged } \geqslant 18 \text { years } \\
\text { with a diagnosis of pulmonary } \\
\text { TB, and receiving outpatient } \\
\text { TB treatment from one of } \\
\text { three TB clinics }\end{array}$ & $\begin{array}{l}\text { To explore the TB treatment- } \\
\text { seeking process of Ugandan } \\
\text { women in order to } \\
\text { determine the routes to } \\
\text { effective government TB } \\
\text { treatment }\end{array}$ & $\begin{array}{l}\text { Private providers and } \\
\text { traditional healer costs }\end{array}$ & Both \\
\hline Datiko and Lindtjørn (2010) [48] & Ethiopia & $\begin{array}{l}\text { Cost-effectiveness } \\
\text { analysis }\end{array}$ & 229 smear-positive patients & $\begin{array}{l}\text { To determine the cost and } \\
\text { cost-effectiveness of } \\
\text { involving health extension } \\
\text { workers in TB treatment } \\
\text { under a community-based } \\
\text { model }\end{array}$ & $\begin{array}{l}\text { Time, caregiver, food, } \\
\text { direct, and total costs }\end{array}$ & Post-diagnosis \\
\hline
\end{tabular}


Table 1 Summary of Studies (Continued)

\begin{tabular}{|c|c|c|c|c|c|c|}
\hline Edginton, et al. (2002) [49] & South Africa & Qualitative & $\begin{array}{l}114 \text { hospital TB patients and } \\
75 \text { clinic TB patients and } \\
\text { community members were } \\
\text { interviewed }\end{array}$ & $\begin{array}{l}\text { To assess the beliefs and } \\
\text { experiences about TB from } \\
\text { the perspective of patients } \\
\text { and community members } \\
\text { in order to assess the } \\
\text { impact of presentation to } \\
\text { health services and treatment } \\
\text { adherence }\end{array}$ & Time and travel costs & Post-diagnosis \\
\hline Floyd, et al. (2003) [50] & Malawi & $\begin{array}{l}\text { Cost-effectiveness } \\
\text { analysis }\end{array}$ & $\begin{array}{l}2,174 \text { new smear-positive } \\
\text { and -negative patients } \\
\text { registered for treatment in } \\
\text { 1997; } 2,821 \text { new smear- } \\
\text { positive and -negative patients } \\
\text { registered for treatment } \\
\text { in } 1998\end{array}$ & $\begin{array}{l}\text { To assess the cost and } \\
\text { cost-effectiveness of new } \\
\text { treatment strategies for } \\
\text { new pulmonary TB patients } \\
\text { introduced in Malawi in } 1997\end{array}$ & $\begin{array}{l}\text { Time, travel, } \\
\text { hospitalization, } \\
\text { caregiver, and DOTS } \\
\text { costs }\end{array}$ & Post-diagnosis \\
\hline Floyd, et al. (1997) [51] & South Africa & $\begin{array}{l}\text { Cost-effectiveness } \\
\text { analysis }\end{array}$ & $\begin{array}{l}\text { New smear-positive adult } \\
\text { patients }\end{array}$ & $\begin{array}{l}\text { To conduct an economic } \\
\text { evaluation of directly } \\
\text { observed treatment and } \\
\text { conventionally delivered } \\
\text { treatment for the } \\
\text { management of new adult } \\
\text { TB cases }\end{array}$ & $\begin{array}{l}\text { Time, travel, } \\
\text { hospitalization, total, } \\
\text { and DOTS costs }\end{array}$ & Post-diagnosis \\
\hline Gibson, et al. (1998) [52] & Sierra Leone & Cross-sectional & $\begin{array}{l}54 \text { inpatients, } 18 \text { outpatients, } \\
\text { and } 17 \text { staff members in } 6 \\
\text { TB Centers }\end{array}$ & $\begin{array}{l}\text { To evaluate the impact of } \\
\text { patient poverty and } \\
\text { staff salaries on patient } \\
\text { costs for TB treatment } \\
\text { within a sub-national } \\
\text { TB program }\end{array}$ & $\begin{array}{l}\text { Pre-program, program } \\
\text { time, and total costs }\end{array}$ & Both \\
\hline Harper, et al. (2003) [53] & The Gambia & Qualitative & $\begin{array}{l}443 \text { patients and clinic staff } \\
\text { participated in focus groups, } \\
\text { in-depth interviews, and } \\
\text { semi-structured interviews }\end{array}$ & $\begin{array}{l}\text { To evaluate the factors related } \\
\text { to shortages of case tracing } \\
\text { and adherence to treatment } \\
\text { using qualitative methods } \\
\text { with a cohort of TB patients }\end{array}$ & $\begin{array}{l}\text { Travel and private } \\
\text { treatment costs }\end{array}$ & Both \\
\hline Kemp, et al. (2007) [54] & Malawi & Cross-sectional & $\begin{array}{l}179 \text { smear-positive and } \\
\text {-negative TB patients who } \\
\text { were in the intensive phase } \\
\text { of treatment }\end{array}$ & $\begin{array}{l}\text { To assess the relative } \\
\text { costs of accessing a TB } \\
\text { diagnosis for the poor } \\
\text { and for women in urban } \\
\text { Lilongwe, Malawi, where } \\
\text { public health services are } \\
\text { accessible within } 6 \mathrm{~km} \\
\text { and are provided free of } \\
\text { charge }\end{array}$ & $\begin{array}{l}\text { Time, travel, } \\
\text { medication, } \\
\text { and food costs }\end{array}$ & Both \\
\hline Mesfin, et al. (2010) [55] & Ethiopia & Prospective cohort & $\begin{array}{l}537 \text { newly diagnosed } \\
\text { smear-positive } \\
\text { pulmonary TB patients } \\
\text { and } 387 \text { newly diagnosed } \\
\text { smear-negative pulmonary TB } \\
\text { patients } \geq 15\end{array}$ & $\begin{array}{l}\text { To investigate costs of } \\
\text { TB diagnosis incurred by } \\
\text { patients, their escorts, } \\
\text { and the public health } \\
\text { system in } 10 \text { districts in } \\
\text { Ethiopia }\end{array}$ & $\begin{array}{l}\text { Caregiver, time, } \\
\text { travel, medication, } \\
\text { consultation, hospital } \\
\text { admission, and } \\
\text { lodging costs }\end{array}$ & Both \\
\hline
\end{tabular}


Table 1 Summary of Studies (Continued)

\begin{tabular}{|c|c|c|c|c|c|c|}
\hline Moalosi, et al. (2003) [56] & Botswana & $\begin{array}{l}\text { Cost-effectiveness } \\
\text { analysis }\end{array}$ & $\begin{array}{l}50 \text { caregivers of TB patients } \\
\text { on home-based care }\end{array}$ & $\begin{array}{l}\text { To determine the affordability } \\
\text { and cost-effectiveness of } \\
\text { home-based DOTS vs. hospital- } \\
\text { based DOTS for TB patients and } \\
\text { to describe the characteristics } \\
\text { of patients and their caregivers }\end{array}$ & $\begin{array}{l}\text { Total, time, travel, } \\
\text { medication and } \\
\text { hospitalization costs } \\
\text { for caregivers }\end{array}$ & Both \\
\hline Needham, et al. (1996) [57] & Zambia & Cross-sectional & $\begin{array}{l}23 \text { adult inpatients and } \\
\text { outpatients with a diagnosis } \\
\text { of pulmonary TB }\end{array}$ & $\begin{array}{l}\text { Letter in response to Pocock } \\
\text { et al. } 1996 \text { to assess patient- } \\
\text { related economic barriers to } \\
\text { TB diagnosis in Lusaka, Zambia }\end{array}$ & $\begin{array}{l}\text { Medical, non-medical, } \\
\text { time, and caregiver } \\
\text { costs }\end{array}$ & Both \\
\hline Needham, et al. (1998) [58] & Zambia & Cross-sectional & $\begin{array}{l}202 \text { adult inpatients and } \\
\text { outpatients registering with } \\
\text { new pulmonary TB at the } \\
\text { Chest Clinic }\end{array}$ & $\begin{array}{l}\text { To study the pre-diagnosis } \\
\text { economic impact burden and } \\
\text { barrers to care seeking for TB } \\
\text { patients in urban Zambia }\end{array}$ & $\begin{array}{l}\text { Time, travel, consultation, } \\
\text { caregiver, private } \\
\text { provider, traditional healer, } \\
\text { insurance, diagnostic, } \\
\text { treatment, and food costs }\end{array}$ & Both \\
\hline Needham, et al. (2004) [59] & Zambia & Qualitative & $\begin{array}{l}202 \text { adult patients with } \\
\text { pulmonary tuberculosis }\end{array}$ & $\begin{array}{l}\text { To assess the barriers to } \\
\text { successful care seeking faced } \\
\text { by TB patients in urban Zambia }\end{array}$ & $\begin{array}{l}\text { Time, travel, caregiver, } \\
\text { and government health } \\
\text { insurance costs }\end{array}$ & Pre-diagnosis \\
\hline Nganda, et al. (2003) [60] & Kenya & $\begin{array}{l}\text { Cost-effectiveness } \\
\text { analysis }\end{array}$ & $\begin{array}{l}\text { New smear-positive, new } \\
\text { smear-negative and extra- } \\
\text { pulmonary adult patients; for } \\
\text { each type of patient, two } \\
\text { alternative approaches to } \\
\text { treatment were evaluated: } \\
\text { the conventional approach } \\
\text { used until September } 1997 \\
\text { and the new approach } \\
\text { introduced in October } 1997\end{array}$ & $\begin{array}{l}\text { To assess the cost and cost- } \\
\text { effectiveness of new treatment } \\
\text { strategies, involving } \\
\text { decentralization of care from } \\
\text { hospitals to peripheral health } \\
\text { facilities and the community, } \\
\text { compared to the conventional } \\
\text { approaches used until } \\
\text { October } 1997\end{array}$ & $\begin{array}{l}\text { Total, travel, } \\
\text { hospitalization, } \\
\text { TB clinic, and DOTS } \\
\text { costs }\end{array}$ & Post-diagnosis \\
\hline Okello, et al. (2003) [61] & Uganda & $\begin{array}{l}\text { Cost-effectiveness } \\
\text { analysis }\end{array}$ & $\begin{array}{l}\text { New smear-positive pulmonary } \\
\text { patients under two strategies: } \\
\text { the conventional hospital- } \\
\text { based approach used from } \\
1995 \text { thorough 1997, and the } \\
\text { new community-based } \\
\text { approach introduced in } 1998\end{array}$ & $\begin{array}{l}\text { To assess the cost and cost- } \\
\text { effectiveness of conventional } \\
\text { hospital-based care with the } \\
\text { new community-based care } \\
\text { for new smear-positive } \\
\text { pulmonary TB patients }\end{array}$ & $\begin{array}{l}\text { Time, travel, } \\
\text { hospitalization, and } \\
\text { total DOTS costs }\end{array}$ & Post-diagnosis \\
\hline Pocock, et al. (1996) [62] & Malawi & Cross-sectional & $\begin{array}{l}100 \text { adult patients with smear- } \\
\text { positive and extrapulmonary } \\
\text { TB admitted to the TB ward, } \\
\text { Queen Elizabeth Central } \\
\text { Hospital, for } 2 \text { months of } \\
\text { treatment }\end{array}$ & $\begin{array}{l}\text { Letter investigating impacts } \\
\text { of long hospitalization from } \\
\text { the patients' perspective }\end{array}$ & Time costs & Post-diagnosis \\
\hline Saunderson, P.R. (1995) [31] & Uganda & $\begin{array}{l}\text { Cost-effectiveness } \\
\text { analysis }\end{array}$ & $\begin{array}{l}34 \text { patients attending a } \\
\text { hospital run by a non- } \\
\text { governmental } \\
\text { organization }\end{array}$ & $\begin{array}{l}\text { To analyze the costs and } \\
\text { cost-effectiveness of the } \\
\text { current TB control strategy } \\
\text { and an alternative ambulatory } \\
\text { treatment strategy }\end{array}$ & $\begin{array}{l}\text { Total, time, hospitalization, } \\
\text { and pre-diagnosis costs }\end{array}$ & Both \\
\hline
\end{tabular}


Table 1 Summary of Studies (Continued)

\begin{tabular}{|c|c|c|c|c|c|c|}
\hline Sinanovic, et al. (2003) [63] & South Africa & $\begin{array}{l}\text { Cost-effectiveness } \\
\text { analysis }\end{array}$ & $\begin{array}{l}\text { New smear-positive } \\
\text { and retreatment pulmonary } \\
\text { TB patients started on } \\
\text { treatment in two townships } \\
\text { of Metropolitan Cape Town } \\
\text { (Guguletu, where both clinic } \\
\text { and community care were } \\
\text { provided, and Nyanga, where } \\
\text { only clinic-based care was } \\
\text { provided) }\end{array}$ & $\begin{array}{l}\text { To evaluate the affordability } \\
\text { and cost-effectiveness of } \\
\text { community involvement in } \\
\text { TB care }\end{array}$ & $\begin{array}{l}\text { Total, time, and } \\
\text { travel costs }\end{array}$ & Post-diagnosis \\
\hline $\begin{array}{l}\text { Sinanovic and Kumaranay-ake } \\
\text { (2006) [64] }\end{array}$ & South Africa & $\begin{array}{l}\text { Cost-effectiveness } \\
\text { analysis }\end{array}$ & $\begin{array}{l}1,182 \text { new sputum positive } \\
\text { patients at } 2 \text { public-private } \\
\text { workplace sites (PWP), } 2 \text { public- } \\
\text { non-governmental organization } \\
\text { partnership sites (PNP) and } 2 \\
\text { purely public sites }\end{array}$ & $\begin{array}{l}\text { To estimate the cost and cost- } \\
\text { effectiveness of different types of } \\
\text { public-private-partnerships in TB } \\
\text { treatment and the financing } \\
\text { required for the different models } \\
\text { from the provincial TB program from } \\
\text { the patient and provider perspective }\end{array}$ & $\begin{array}{l}\text { Total, time, and } \\
\text { travel costs }\end{array}$ & Post-diagnosis \\
\hline Steen and Mazonde (1999) [30] & Botswana & Cross-sectional & $\begin{array}{l}212 \text { New and retreated } \\
\text { patients with smear-positive } \\
\text { pulmonary TB }\end{array}$ & $\begin{array}{l}\text { To estimate the health-seeking } \\
\text { behaviors of TB patients and their } \\
\text { beliefs and attitudes of the disease }\end{array}$ & Outpatient fees & Post-diagnosis \\
\hline Vassall, et al. (2010) [65] & Ethiopia & Cross-sectional & $\begin{array}{l}250 \text { patients } \geqslant 15 \text { years using } \\
\text { TB-HIV pilot services and } \\
\text { diagnosed with and being } \\
\text { treated for TB, HIV, or both }\end{array}$ & $\begin{array}{l}\text { To measure patients costs of } \\
\text { TB-HIV services from hospital- } \\
\text { based pilot sites for collaborative } \\
\text { TB-HIV interventions }\end{array}$ & $\begin{array}{l}\text { Direct, indirect, } \\
\text { transport, total }\end{array}$ & Both \\
\hline Wandwalo, et al. (2005) [66] & Tanzania & $\begin{array}{l}\text { Cost-effectiveness } \\
\text { analysis }\end{array}$ & $\begin{array}{l}42 \text { treatment supervisors and } \\
103 \text { new smear-positive, smear- } \\
\text { negative, and extrapulmonary } \\
\text { TB patients } 5 \text { years }\end{array}$ & $\begin{array}{l}\text { To determine the cost and cost- } \\
\text { effectiveness of community-based } \\
\text { DOTS versus health facility } \\
\text { treatment of TB in urban Tanzania }\end{array}$ & $\begin{array}{l}\text { Direct, indirect, time, } \\
\text { and total costs }\end{array}$ & Post-diagnosis \\
\hline Wilkinson, et al. (1997) [67] & South Africa & $\begin{array}{l}\text { Cost-effectiveness } \\
\text { analysis }\end{array}$ & $\begin{array}{l}\text { TB patients under the Hlabisa } \\
\text { strategy (1991-preent), the } \\
\text { former Hlabisa strategy (until 1991), } \\
\text { the Department of Health strategy, } \\
\text { and the SANTA strategy based on } \\
\text { sanatorium care }\end{array}$ & $\begin{array}{l}\text { To conduct an economic analysis } \\
\text { of the Hlabisa community-based } \\
\text { DOTS management compared to } \\
\text { three alternative strategies }\end{array}$ & $\begin{array}{l}\text { Total, hospitalization, } \\
\text { and travel costs }\end{array}$ & Post-diagnosis \\
\hline Wyss, et al. (2001) [68] & Tanzania & Cross-sectional & $\begin{array}{l}191 \text { TB cases in } 3 \text { surveillance } \\
\text { areas who had smear-positive, } \\
\text { extrapulmonary, or relapse TB }\end{array}$ & $\begin{array}{l}\text { To assess household level costs } \\
\text { of TB and to compare them with } \\
\text { provider costs of the National TB } \\
\text { Control Program }\end{array}$ & $\begin{array}{l}\text { Diagnostic test, time, } \\
\text { traditional healer, private } \\
\text { provider, hospitalization, } \\
\text { caregiver, and travel costs }\end{array}$ & Both \\
\hline
\end{tabular}


Table 2 Types of Costs

\begin{tabular}{|c|c|c|c|c|c|}
\hline Cost categories & Definition & $\begin{array}{l}\text { Direct or } \\
\text { indirect }\end{array}$ & $\begin{array}{l}\text { Pre- or } \\
\text { post-diagnosis }\end{array}$ & $\begin{array}{l}\text { Number of } \\
\text { studies reporting } \\
\text { cost category }\end{array}$ & $\begin{array}{l}\text { Range (median) } \\
\text { of costs }\end{array}$ \\
\hline Health insurance & $\begin{array}{l}\text { Costs required for national health } \\
\text { insurance schemes to finance } \\
\text { TB care }\end{array}$ & Direct & Pre-diagnosis & 2 & $1 \$ 2-1 \$ 3(1 \$ 2)$ \\
\hline $\begin{array}{l}\text { Consultation or } \\
\text { prepayment fees }\end{array}$ & $\begin{array}{l}\text { Costs charged by providers before } \\
\text { diagnosis or treatment }\end{array}$ & Direct & Pre-diagnosis & 4 & $1 \$ 2-1 \$ 7(1 \$ 3)$ \\
\hline Private provider fees & $\begin{array}{l}\text { Costs charged in the private sector } \\
\text { rather than the public sector }\end{array}$ & Direct & Both & 4 & $|\$ 24-| \$ 141(\mid \$ 41)$ \\
\hline Hospitalization & $\begin{array}{l}\text { Costs associated with hospitalization } \\
\text { due to TB }\end{array}$ & Direct & Post-diagnosis & 10 & $1 \$ 1-\mid \$ 530(\mid \$ 80)$ \\
\hline Medication & $\begin{array}{l}\text { Costs of medications including } \\
\text { standard TB treatment under } \\
\text { non-DOTS systems and other drugs }\end{array}$ & Direct & Post-diagnosis & 5 & $1 \$ 15-\mid \$ 548(\mid \$ 21)^{a}$ \\
\hline Diagnostic tests & $\begin{array}{l}\text { Costs for tests other than sputum } \\
\text { microscopy such as } x \text {-rays, chest } \\
\text { radiographs, or other laboratory tests }\end{array}$ & Direct & Pre-diagnosis & 3 & I\$7- $\mid \$ 10(\mid \$ 9)$ \\
\hline Traditional healer & $\begin{array}{l}\text { Costs associated with seeking } \\
\text { traditional healers before Western } \\
\text { medical care }\end{array}$ & Direct & Pre-diagnosis & 5 & I\$4- I\$563 (I\$15) \\
\hline Food & $\begin{array}{l}\text { Costs for regular food and food } \\
\text { separate from normal diets such as } \\
\text { potatoes, eggs, meat, fruit, and } \\
\text { soft drinks [58] }\end{array}$ & Direct & Post-diagnosis & 4 & $1 \$ 4-1 \$ 36(\mid \$ 10)$ \\
\hline Travel & $\begin{array}{l}\text { Costs for travel association with } \\
\text { pre-diagnosis, consultation, } \\
\text { diagnosis, treatment, pill collection, } \\
\text { DOTS and follow-up treatment visits. }\end{array}$ & Direct & Both & 18 & $1 \$ 0.17-1 \$ 70(1 \$ 5)$ \\
\hline Time & $\begin{array}{l}\text { Time and indirect costs associated } \\
\text { with time spent seeking/receiving } \\
\text { care and lost work time }\end{array}$ & Indirect & Both & 21 & $|\$ 0.23-| \$ 412(\mid \$ 16)^{b}$ \\
\hline Caregiver & $\begin{array}{l}\text { Costs to those accompanying } \\
\text { patients to TB care visits, retrieving } \\
\text { medications on their behalf, or cost } \\
\text { of care-giving activities. Direct costs } \\
\text { encompass travel expenses, food, } \\
\text { or other costs such as paying for } \\
\text { an overnight stay when making a } \\
\text { long journey. Indirect costs include } \\
\text { loss of income and time spent } \\
\text { accompanying patients or providing } \\
\text { care-giving activities. }\end{array}$ & Both & Both & 8 & $|\$ 0.41-| \$ 1,510(\mid \$ 11)^{c}$ \\
\hline
\end{tabular}

\footnotetext{
${ }^{a}$ Note: Some medication estimates also include the cost of user/consultation fees; ${ }^{b}$ Costs include only reported costs of income lost due to time; ${ }^{c}$ Based on
} different categories of costs.

ranged from I\$11 in Zambia [41] to over I\$527 in Ethiopia [65], while indirect costs ranged from I\$21 in Zambia [41] to I\$145 in Ethiopia [55]. Thirteen studies reported overall total costs (direct and indirect), which ranged from $\mathbf{I} \$ 2$ in South Africa [63] to I\$584 in Uganda [31] (see Table 7).

Five studies reported the percentage of all costs that patients paid out-of-pocket. In South Africa, out-of-pocket expenses varied by district in which patients were responsible for paying between $13 \%$ and $34 \%$ of all costs [51]. Similarly, in Tanzania patients paid between $13 \%$ and $30 \%$ of total costs in community-based DOTS and health facility-based DOTS programs, respectively [66]. In Malawi and Ethiopia, patients paid close to $50 \%$ of total costs of their care.

\section{Caregiver and guardian costs}

Eight studies reported both direct and indirect costs incurred by TB patients' guardians or caregivers. Direct costs included transportation costs that ranged from less than I\$1 (standard deviation [SD] I\$4) under a community-based DOTS program in Ethiopia [48] to I $\$ 27$ in Botswana [56]. The amount of time spent traveling for one care-related visit ranged from 20 minutes in Botswana [56] to 17 hours (median 0) in Ethiopia [55]. Other direct costs for caregivers included food costs that ranged from I\$3 (standard deviation [SD] I\$5) in Ethiopia [48] to $\mathbf{I} \$ 1,209$ in Botswana [56] and time spent providing care-giving activities, which ranged from 1 hour each day in Botswana [59] to 6 days 
Table 3 Health insurance, consultation/prepayment fees and private provider fees

\begin{tabular}{|c|c|c|c|c|c|}
\hline Author(s) (year) & Country & $\begin{array}{l}\text { Cost } \\
\text { estimate (I\$) }\end{array}$ & $\begin{array}{l}\text { \% Annual per- } \\
\text { capita income } \\
\text { (entire population) }\end{array}$ & $\begin{array}{l}\% \text { Annual per- } \\
\text { capita income } \\
\text { (income-poorest } 20 \% \\
\text { of the population) }\end{array}$ & Notes \\
\hline \multicolumn{6}{|l|}{ Health insurance costs } \\
\hline Aspler, et al. [41] & Zambia & 2 & 0.43 & 2 & $\begin{array}{l}67 \% \text { of patients reported paying } \\
\text { median health insurance user fees } \\
\text { (IQR I\$1.79- I\$1.97) }\end{array}$ \\
\hline Needham, et al. [59] & Zambia & 3 & 0.69 & $3^{a}$ & $\begin{array}{l}\text { Mean monthly fees for government- } \\
\text { sponsored health insurance } \\
\text { (range } 1 \$ 2-1 \$ 3 \text { ) }\end{array}$ \\
\hline \multicolumn{6}{|c|}{ Consultation/prepayment fees } \\
\hline Aspler, et al. [41] & Zambia & 4 & 0.78 & 4 & $\begin{array}{l}\text { Median one time consultation fee } \\
\text { (IQR I\$4- I\$7) }\end{array}$ \\
\hline Mesfin, et al. [55] & Ethiopia & 2 & 0.93 & 2 & $\begin{array}{l}\text { Mean consultation fees per visit } \\
\text { (median I\$0) }\end{array}$ \\
\hline Needham, et al. [58] & Zambia & 7 & 2 & 10 & $\begin{array}{l}\text { Mean one-time consultation fees } \\
\text { (median I\$8) }\end{array}$ \\
\hline Steen and Masonde [30] & Botswana & 2 & 0.06 & $0.43^{\mathrm{b}}$ & One-time prepayment outpatient fee \\
\hline \multicolumn{6}{|l|}{ Private provider fees } \\
\hline Chard, S. [47] & Uganda & 141 & 47 & $154^{c}$ & Private clinic treatment costs \\
\hline Harper, et al. [53] & The Gambia & 44 & 11 & $54^{d}$ & Costs spent on private treatment \\
\hline Needham, et al. [58] & Zambia & 24 & 6 & 35 & $\begin{array}{l}\text { Mean costs to see a private physician } \\
\text { (median I\$15) }\end{array}$ \\
\hline Wyss, et al. [68] & Tanzania & 38 & 12 & $29^{e}$ & Unit cost for private services \\
\hline
\end{tabular}

(median 1) for hospitalized patients in Ethiopia [55]. Indirect costs included foregone earnings for caregivers which ranged from I\$19 (median \$10) in Zambia [58] to I\$89 in Ethiopia [55]. Total reported caregiver cost ranged from $\mathrm{I} \$ 24$ (median I\$12) in Zambia [58] to I $\$ 1510$ under a home-based care strategy in Botswana [56].

\section{Catastrophic costs}

Twenty studies reported costs that were found to be catastrophic for those with average income, and twentyfive studies had costs that were catastrophic for the lowest income earners (see Table 8). Catastrophic costs constituted between $11 \%$ of average annual income in The Gambia for private providers [53] and almost three times average annual income in Ethiopia for total pretreatment costs [65]. For those in the income-poorest $20 \%$ of a country's population, catastrophic costs constituted between $10 \%$ of annual income for traditional healers in Tanzania [68] to roughly ten times annual income for hospitalization costs in Malawi [50].

Two aspects of our extracted data are important to note in this context: First, we extracted data for a range of different cost categories (Tables 1, 2, 3, 4, 5). For all cost categories, there are at least a few studies reporting catastrophic costs according to our definition both for those with average income and those with the average income among the income-poorest $20 \%$ of the population: traditional healer, food, travel, private provider, medication, "tipping" providers, hospitalization, caregiver, and overall direct, indirect and total costs. Second, the extracted costs are presented in the tables in the units they were reported in the original papers because we did not have sufficient information, either from the papers or external sources, to allow translation into a common unit. However, catastrophic costs were found in all units of reported costs, including per-visit, per time period, and per treatment course and in both the pre- and post-diagnosis periods.

\section{Discussion}

In expanding on a previous review of $\mathrm{TB}$ patient costs in sub-Saharan Africa [23], we extended the evidence base on TB patient costs in sub-Saharan Africa through screening of additional databases and broadening the study design inclusion criteria. We have further added to the literature by systematically identifying the particular types of costs TB patient incur and by systematically reviewing the evidence on the cost quantities for each cost type. Our review furthermore provides benchmarks for the magnitude of these cost burdens by comparing them to average income earners and the average income of the income-poorest $20 \%$ of the population. 
Table 4 Hospitalization, medication, and diagnostic test costs

\begin{tabular}{|c|c|c|c|c|c|}
\hline Author(s) (year) & Country & $\begin{array}{l}\text { Cost } \\
\text { estimate (I\$) }\end{array}$ & $\begin{array}{l}\% \text { Annual per- } \\
\text { capita income } \\
\text { (entire population) }\end{array}$ & $\begin{array}{l}\% \text { Annual per- } \\
\text { capita income } \\
\text { (income-poorest } 20 \% \\
\text { of the population) }\end{array}$ & Notes \\
\hline \multicolumn{6}{|l|}{ Hospitalization costs } \\
\hline Aspler, et al. [41] & Zambia & 14 & 3 & 16 & Median costs (IQR I\$4- I\$19) \\
\hline Floyd, et al. [51] & South Africa & 119 & 3 & $17^{a}$ & $\begin{array}{l}\text { Mean cost of 18-day hospital stay } \\
\text { under DOTS (I\$7 per day) }\end{array}$ \\
\hline Floyd, et al. [51] & South Africa & 407 & 11 & $59^{a}$ & $\begin{array}{l}\text { Mean cost of 60-day hospital stay } \\
\text { under conventional system ( } \$ \$ 7 / \text { day) }\end{array}$ \\
\hline Floyd, et al. [50] & Malawi & 498 & 262 & 1048 & $\begin{array}{l}\text { Mean cost of 58-day hospital stay } \\
\text { under hospital-based strategy for } \\
\text { smear-positive patients (I\$9/day) }\end{array}$ \\
\hline Floyd, et al. [50] & Malawi & 138 & 73 & 289 & $\begin{array}{l}\text { Mean cost of 16-day hospital stay } \\
\text { under community-based DOTS strategy } \\
\text { for smear-positive patients (I\$9/day) }\end{array}$ \\
\hline Floyd, et al. [50] & Malawi & 32 & 17 & 66 & $\begin{array}{l}\text { Mean cost of 8-day hospital stay under } \\
\text { hospital-based and community-based } \\
\text { DOTS strategies for smear-negative } \\
\text { patients (I\$9/day) }\end{array}$ \\
\hline Gibson and Boillot [52] & Sierra Leone & 1 & 0.53 & $2^{b}$ & $\begin{array}{l}\text { Mean hospital admission fees at a } \\
\text { missionary hospital }\end{array}$ \\
\hline Gibson and Boillot [52] & Sierra Leone & 47 & 18 & $58^{\mathrm{b}}$ & $\begin{array}{l}\text { Mean hospital admission fees at a } \\
\text { government hospital }\end{array}$ \\
\hline Mesfin, et al. [55] & Ethiopia & 4 & 2 & 5 & $\begin{array}{l}\text { Mean cost of hospital admissions } \\
\text { (median } 1 \$ 0)\end{array}$ \\
\hline Nganda, et al. [60] & Kenya & 530 & 101 & $336^{c}$ & $\begin{array}{l}\text { Mean cost of 60-day hospital stay } \\
\text { under hospital-based system for smear- } \\
\text { positive patients ( } \$ \$ 9 / \text { day) ( } 96 \% \text { Cl } \$ 5-1 \$ 13)\end{array}$ \\
\hline Nganda, et al. [60] & Kenya & 34 & 7 & $22^{c}$ & $\begin{array}{l}\text { Mean cost of 4-day hospital stay under } \\
\text { community-based DOTS for smear- } \\
\text { positive patients (I\$9/ day) ( } 96 \% \mathrm{CI}|\$ 5-| \$ 13)\end{array}$ \\
\hline Okello, et al. [61] & Uganda & 219 & 73 & $240^{d}$ & $\begin{array}{l}\text { Mean cost of 60-day hospital stay under } \\
\text { conventional hospital-based care strategy } \\
\text { for smear-positive patients (I\$4/ day) }\end{array}$ \\
\hline Okello, et al. [61] & Uganda & 70 & 24 & $77^{d}$ & $\begin{array}{l}\text { Mean cost of 19-day hospital stay under } \\
\text { community-based care strategy for smear- } \\
\text { positive patients ( } \$ 4 / \text { day) }\end{array}$ \\
\hline Saunderson, P. [31] & Uganda & 91 & 39 & 126 & Mean cost for a 2-month hospital stay \\
\hline Wilkinson, et al. [67] & South Africa & 139 & 3.62 & $20^{e}$ & $\begin{array}{l}\text { Mean cost of 17.5-day hospital stay under } \\
\text { community-based DOTS strategy ( } \$ \$ 8 / \text { day) }\end{array}$ \\
\hline Wyss et al. [68] & Tanzania & 15 & 5 & $12^{f}$ & $\begin{array}{l}\text { Hospitalization costs reported for one } \\
\text { month }\end{array}$ \\
\hline \multicolumn{6}{|l|}{ Medication costs } \\
\hline Aspler, et al. [41] & Zambia & 15 & 3 & 18 & $\begin{array}{l}\text { Median costs for additional medications } \\
\text { (IQR I\$9- I\$21) }\end{array}$ \\
\hline Awofeso, N. [42] & Nigeria & $548^{9}$ & 121 & $589^{h}$ & $\begin{array}{l}\text { Mid-range, one-time medication costs } \\
(\text { range } \mid \$ 199-1 \$ 897)^{9}\end{array}$ \\
\hline Chard, S. [46] & Uganda & 20 & 7 & $22^{i}$ & Mean costs for medications (range $1 \$ 4-1 \$ 37$ ) \\
\hline Kemp, et al. [54] & Malawi & 50 & 27 & $106^{j}$ & $\begin{array}{l}\text { Mean costs for smear-negative patients for } \\
\text { user fees and drug costs outside of } \\
\text { government health facilities (median } 1 \$ 19 \text { ) }\end{array}$ \\
\hline Kemp, et al. [54] & Malawi & 18 & 9 & $37^{j}$ & $\begin{array}{l}\text { Mean costs for smear-positive patients for } \\
\text { user fees and drug costs outside of } \\
\text { government health facilities (median } 1 \$ 6 \text { ) }\end{array}$ \\
\hline Mesfin, et al. [55] & Ethiopia & 22 & 12 & 25 & $\begin{array}{l}\text { Mean costs for additional medications } \\
\text { (median } 1 \$ 7 \text { ) }\end{array}$ \\
\hline
\end{tabular}


Table 4 Hospitalization, medication, and diagnostic test costs (Continued)

\begin{tabular}{llllll}
\hline Diagnostic test costs & & & & \\
\hline Aspler, et al. [41] & Zambia & 7 & 2 & 8 & $\begin{array}{l}\text { Median cost for chest radiographic } \\
\text { (IQR I\$4-I\$7) }\end{array}$ \\
\hline Needham, et al. [58] & Zambia & 9 & 2 & 13 & $\begin{array}{l}\text { Mean cost for diagnostic tests (unspecified) } \\
\text { (median I\$13) }\end{array}$ \\
\hline Wyss, et al. [68] & Tanzania & 10 & 3 & $7^{f}$ & $\begin{array}{l}\text { Unit cost for examination, laboratory, and } \\
\text { X-rays }\end{array}$ \\
\hline
\end{tabular}

${ }^{a}$ Income share based on 1995 estimates instead of $1994 ;{ }^{b}$ Income share assumed to be $6 \%$ by authors in absence of World Bank data; ${ }^{c}$ Income share based on

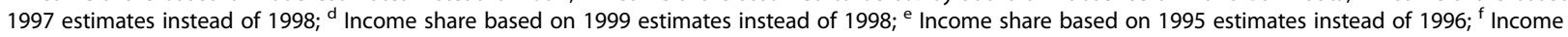
share based on 2000 estimates instead of 1996; ${ }^{9}$ Note: the study listed these costs as "prepayment fees," but the costs were actually for medications. Moreover, these medication costs are reported with imprecision (i.e., a wide range), weakening the strength of the conclusion that TB medication costs were high in Nigeria; ${ }^{\mathrm{h}}$ Income share based on 1992 estimates instead of $1993 ;{ }^{i}$ Income share based on 1999 estimates instead of $1998 ;{ }^{j}$ Income share based on 1998 estimates instead of 2000.

The data reviewed here demonstrate that direct and indirect patient costs for TB patients and their households can be substantial and often "catastrophic" for average income earners and, in particular, for those in the income-poorest $20 \%$ of the population-the proportion of the population most at-risk of acquiring TB. The data we extracted from the literature thus suggest that expenditures for TB treatment and care can cause or exacerbate poverty. TB patients in sub-Saharan
Africa incur both substantial direct and indirect costs before, during, and after a TB diagnosis. The largest costs these patients incur are for hospitalization, medication, transportation, and treatment or care in the private sector. In addition, caregivers incur substantial indirect, or time costs, of providing care or support for TB patients.

Results also show that total TB treatment and care costs vary greatly between studies: from only I $\$ 2$ in

Table 5 Traditional healer and food costs

\begin{tabular}{|c|c|c|c|c|c|}
\hline Author(s) (year) & Country & $\begin{array}{l}\text { Cost } \\
\text { estimate (I\$) }\end{array}$ & $\begin{array}{l}\% \text { Annual per- } \\
\text { capita income } \\
\text { (entire population) }\end{array}$ & $\begin{array}{l}\% \text { Annual per- } \\
\text { capita income } \\
\text { (income-poorest 20\% } \\
\text { of the population) }\end{array}$ & Notes \\
\hline \multicolumn{6}{|l|}{ Traditional healer costs } \\
\hline Brouwer, et al. [44] & Malawi & 4 & 2 & $9^{a}$ & $\begin{array}{l}\text { Weighted mean of traditional healer } \\
\text { costs (range } \mid \$ 0-1 \$ 28)^{b}\end{array}$ \\
\hline Chard, S. [47] & Uganda & 563 & 188 & $618^{c}$ & $\begin{array}{l}\text { One study participant reported this } \\
\text { cost for a traditional healer }\end{array}$ \\
\hline Chard, S. [46] & Uganda & 15 & 5 & $16^{c}$ & $\begin{array}{l}\text { Mid-point estimate (range I\$2-I\$10). } \\
\text { A few patients in the sample reported } \\
\text { to pay roughly } 1 \$ 495\end{array}$ \\
\hline Needham, et al. [58] & Zambia & 17 & 4 & 25 & $\begin{array}{l}\text { Average cost to see a traditional } \\
\text { healer (median } 1 \$ 7)\end{array}$ \\
\hline Wyss, et al. [68] & Tanzania & 13 & 4 & $10^{d}$ & Unit cost to see a traditional healer \\
\hline \multicolumn{6}{|l|}{ Food costs } \\
\hline Aspler, et al. [[41] & Zambia & 4 & 0.78 & 4 & Median food costs (IQR I\$1- I\$7) \\
\hline Datiko and Lindtjørn [48] & Ethiopia & 14 & 7 & $15^{\mathrm{e}}$ & $\begin{array}{l}\text { Mean food costs for a community-based } \\
\text { DOTS treatment program (sd I\$12) }\end{array}$ \\
\hline Datiko and Lindtjørn [48] & Ethiopia & 36 & 17 & $37^{e}$ & $\begin{array}{l}\text { Mean food costs for a health-facility- } \\
\text { based DOTS treatment program (sd I\$21) }\end{array}$ \\
\hline Kemp, et al. [54] & Malawi & 7 & 4 & $15^{f}$ & $\begin{array}{l}\text { Mean food costs for smear-negative } \\
\text { patients (median } 1 \$ 2 \text { ) }\end{array}$ \\
\hline Kemp, et al. [54] & Malawi & 10 & 5 & $21^{f}$ & $\begin{array}{l}\text { Mean food costs for smear-positive } \\
\text { patients (median I\$0) }\end{array}$ \\
\hline Needham, et al. [58] & Zambia & 3 & 1 & 5 & Mean food cost (median $1 \$ 2$ ) \\
\hline Needham, et al. [58] & Zambia & 36 & 9 & 53 & $\begin{array}{l}\text { Mean cost for "special" foods } \\
\text { (median I\$19) }\end{array}$ \\
\hline
\end{tabular}

${ }^{a}$ Income share based on 1998 estimates instead of $1995 ;{ }^{b} 43 \%$ of patients in the sample who sought care from traditional healers paid no charge, $21 \%$ paid under $\$ \$ 0.92,24 \%$ paid between $\mid \$ 0.92$ and $\$ \$ 5,6 \%$ paid between $\$ \$ 6$ and $I \$ 14$, and the remaining $6 \%$ paid between $I \$ 14$ and $I \$ 28 ;{ }^{c}$ Income share based on 1999 estimates instead of 1998; ${ }^{d}$ Income share based on 2000 estimates instead of 1996; ${ }^{\mathrm{e}}$ Income share based on 2005 estimates instead of $2006 ;{ }^{f}$ Income share based on 1998 estimates instead of 2000; ${ }^{9}$ Defined as food separate from normal diets such as potatoes, eggs, meat, fruit, and soft drinks [58]. 
Table 6 Travel costs

\begin{tabular}{|c|c|c|c|c|c|}
\hline Author(s) year & Country & $\begin{array}{l}\text { Cost } \\
\text { estimate (I\$) }\end{array}$ & $\begin{array}{l}\% \text { monthly per- } \\
\text { capita income } \\
\text { (entire population) }\end{array}$ & $\begin{array}{l}\% \text { monthly per- } \\
\text { capital income } \\
\text { (income-poorest 20\% } \\
\text { of the population) }\end{array}$ & Notes \\
\hline Aspler, et al. [41] & Zambia & 3 & 8 & 43 & Median costs for pre-diagnosis (IQR I\$1- |\$7) \\
\hline Aspler, et al. [41] & Zambia & 12 & 31 & 171 & $\begin{array}{l}\text { Median costs for pill collection visits } \\
\text { (IQR I\$4- I\$29) }\end{array}$ \\
\hline Aspler, et al. [41] & Zambia & 4 & 10 & 57 & Median costs for follow-up visits (IQR I\$2- I\$4) \\
\hline Bevan, E. [43] & Kenya & 5 & 11 & 35 & $\begin{array}{l}\text { Daily cost to travel to a designated DOTS } \\
\text { center }\end{array}$ \\
\hline Cambanis, et al. [45] & Ethiopia & 7 & 47 & $100^{a}$ & Mean costs for transport to a health facility \\
\hline Chard, S. [46] & Uganda & 3 & 14 & $45^{\mathrm{b}}$ & $\begin{array}{l}\text { Mean transportation costs to a health } \\
\text { facility in Kampala }\end{array}$ \\
\hline Chard, S. [46] & Uganda & 5 & 21 & $67^{\mathrm{b}}$ & $\begin{array}{l}\text { Mean transportation costs to a health } \\
\text { facility in Mukono }\end{array}$ \\
\hline Datiko and Lindtjorn [48] & Ethiopia & 2 & 14 & $31^{c}$ & $\begin{array}{l}\text { Mean transport costs for a community- } \\
\text { based DOTS treatment program (sd I\$5) }\end{array}$ \\
\hline Datiko and Lindtjorn [48] & Ethiopia & 15 & 88 & $188^{c}$ & $\begin{array}{l}\text { Mean transport costs for a health facility- } \\
\text { based DOTS treatment program (sd I\$43) }\end{array}$ \\
\hline Edginton, et al. [49] & South Africa & 3 & 0.96 & $7^{d}$ & $\begin{array}{l}\text { Mid-point costs for } 69 \% \text { of hospital } \\
\text { attendees and } 48 \% \text { of clinic attendees } \\
\text { (range } 1 \$ 0.52-1 \$ 5)^{\mathrm{e}}\end{array}$ \\
\hline Floyd, et al. [51] & South Africa & 12 & 4 & $20^{f}$ & Mean travel cost for a hospital visit \\
\hline Floyd, et al. [51] & South Africa & 2 & 0.74 & $4^{f}$ & Mean travel cost for a health clinic visit \\
\hline Floyd, et al. [51] & South Africa & 0.17 & 0.05 & $0.30^{f}$ & Mean travel cost for a health clinic DOTS visit \\
\hline Floyd, et al. [51] & South Africa & 0.85 & 0.27 & $1^{f}$ & Mean travel cost for a TB ward DOTS visit \\
\hline Floyd, et al. [50] & Malawi & 4 & 26 & 102 & $\begin{array}{l}\text { Mean costs for visit to a health center to } \\
\text { collect drugs for smear-positive and } \\
\text {-negative patients under hospital and } \\
\text { community-based strategies (I\$18 for } \\
\text { average } 5 \text { visits) }\end{array}$ \\
\hline Harper, et al. [53] & The Gambia & 0.55 & 2 & $8^{g}$ & $\begin{array}{l}\text { Mean daily fare to attend a TB clinic } \\
\text { (range } \$ \$ 0.44-1 \$ 0.66 \text { ) }\end{array}$ \\
\hline Kemp, et al. [54] & Malawi & 18 & 116 & $456^{\mathrm{h}}$ & $\begin{array}{l}\text { Mean transport costs for smear-positive } \\
\text { patients (median } \$ 11 \text { ) }\end{array}$ \\
\hline Kemp, et al. [54] & Malawi & 13 & 81 & $319^{h}$ & $\begin{array}{l}\text { Mean transport costs for smear-negative } \\
\text { patients (median } \$ 5 \text { ) }\end{array}$ \\
\hline Mesfin, et al. [55] & Ethiopia & 11 & 72 & 155 & $\begin{array}{l}\text { Mean transport costs for visiting a public } \\
\text { health facility pre-diagnosis }\end{array}$ \\
\hline Needham, et al. [58] & Zambia & 9 & 26 & 150 & $\begin{array}{l}\text { Mean transportation cost during treatment } \\
\text { (median } \$ \$ 3 \text { ) }\end{array}$ \\
\hline Nganda, et al. [60] & Kenya & 9 & 20 & $67^{i}$ & $\begin{array}{l}\text { Mean cost for a visit to collect drugs from } \\
\text { a health facility for smear-positive patients } \\
\text { under conventional and community-based } \\
\text { strategies for smear-positive patients } \\
(\text { (\$44 for average } 5 \text { visits) }\end{array}$ \\
\hline Okello, et al. [61] & Uganda & 6 & 24 & $78^{k}$ & $\begin{array}{l}\text { Mean costs to the nearest health facility in } \\
\text { an outpatient system and costs to collect } \\
\text { drugs under the conventional hospital-based } \\
\text { care strategy and the community-based } \\
\text { care strategy for smear-positive patients (I\$37 } \\
\text { for average } 5 \text { visits) }\end{array}$ \\
\hline Sinanovic, et al. [63] & South Africa & 0.40 & 0.13 & $0.69^{m}$ & $\begin{array}{l}\text { Mean cost for monitoring and collection of } \\
\text { drugs and a clinic-based DOTS visit in } \\
\text { Guguletu, Cape Town (95\% CI I\$0.20- I\$0.60) }\end{array}$ \\
\hline Sinanovic, et al. [63] & South Africa & 0.30 & 0.09 & $0.52^{\mathrm{m}}$ & $\begin{array}{l}\text { Mean cost for monitoring and collection of } \\
\text { drugs and a clinic-based DOTS visit in Nyanga, } \\
\text { Cape Town }(95 \% \mathrm{Cl}|\$ 0.10-| \$ 0.50)\end{array}$ \\
\hline
\end{tabular}


Table 6 Travel costs (Continued)

\begin{tabular}{|c|c|c|c|c|c|}
\hline Vassall, et al. [65] & Ethiopia & 70 & 444 & 952 & $\begin{array}{l}\text { Mean pretreatment transportation costs } \\
(\text { median } 1 \$ 4)^{n}\end{array}$ \\
\hline Wilkinson, et al. [67] & South Africa & 5 & 2 & $9^{\circ}$ & Average cost of a visit to a village clinic $^{p}$ \\
\hline Wilkinson, et al. [67] & South Africa & 20 & 6 & $34^{\circ}$ & Average cost of a visit to a hospital ${ }^{p}$ \\
\hline Wilkinson, et al. [67] & South Africa & 1 & 0.43 & $2^{\circ}$ & $\begin{array}{l}\text { Average cost of a village clinic DOTS visit, } \\
\text { a community health worker DOTS visit, and } \\
\text { a non-health worker DOTS visit }{ }^{p}\end{array}$ \\
\hline Wyss, et al. [68] & Tanzania & 9 & 32 & $83^{9}$ & Weekly transportation costs \\
\hline \multicolumn{6}{|c|}{ 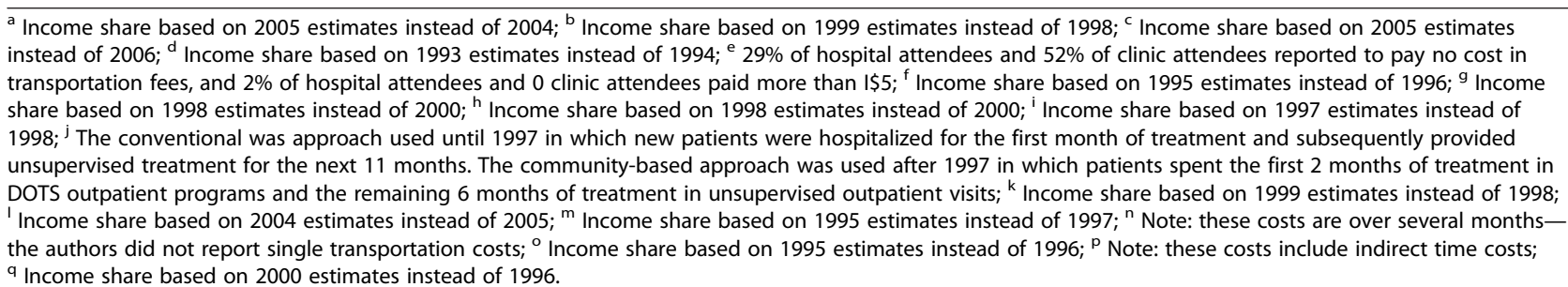 } \\
\hline
\end{tabular}

South Africa [63] to almost $\$ 600$ in Uganda [31] in total estimated costs. Additionally, the types of costs that patients often pay are numerous: eleven main categories of costs were captured in this review, and nine of the thirty studies reported costs in at least five of these cost categories. Though patients in sub-Saharan Africa often do not incur all of these fees, merely paying for one or some of them can have substantial impacts on their economic circumstances.

Patient costs may negatively impact health-seeking behaviors, leading to delays in hospital presentation, further worsening of disease and increasing risk of disease spread [16]. Patients adopt several mechanisms to cope with these costs ranging from asset selling, borrowing, and diversifying income-generating activities $[19,20]$. In order to alleviate the financial burden borne by TB patients, policy makers should consider incorporating policies to support patients receiving TB treatment into general financing and risk-pooling strategies, such as tax-based or social insurance systems as used by many developed and, increasingly, developing economies. While in some settings strategies aimed at reducing patient costs incurred when utilizing healthcare may be feared to lead to increases in demand for healthcare exceeding the underlying need, in many developing countries like those in sub-Saharan Africa, healthcare demand is currently far below need, including for the priority diseases TB and HIV, so that financial and non-financial support for healthcare seeking is likely to contribute substantially to improving population health [70,71]. In addition to the direct benefits to the treated patient, TB treatment also reduces onward transmission of the disease in the community. This positive externality needs to be taken into account when considering public investments to decrease the costs patients bare when utilizing TB care.
Comparable types and extents of costs incurred by patients in sub-Saharan have been found in studies assessing the household financial burden of other infectious diseases including malaria and HIV/AIDS. Although some health districts in sub-Saharan Africa provide free care for HIV/AIDS and malaria patients, studies assessing the burden of expenditures for malaria and HIV/AIDS-affected households have found that costs are commonly "catastrophic," a general finding that conforms with our results for the case of TB. Moreover, the main types of costs that patients and households incurred based on these studies were similar to those found in our review: direct costs of transportation for patients and caregivers, medications, diagnostic tests, hospitalization, food, medical consultations, and traditional healers, as well as the indirect costs such as loss of time at work or school [34,72-76].

More research needs to be done in order to assess the burden of costs to TB patients in other geographical areas, including in the 36 other countries in sub-Saharan Africa for which our systematic review could not identify any empirical estimates of TB treatment and care costs. While our results broadly support calls for health policy changes to alleviate patients' financial burdens of TB treatment, it is unclear which particular interventions will be most effective and cost-effective. Examples of interventions that can reduce the direct patient expenditures for TB treatment include free transport between communities and TB treatment facilities, food vouchers given to TB patients when visiting a facility, and systematic elimination of user fees. Interventions that can reduce indirect patient expenditures for TB treatment include improved health infrastructure, such as, additional TB treatment facilities, better transport infrastructure (to decrease the time spent travelling from a household to a healthcare facility), as well as improved patient scheduling systems (to decrease patient wait times at healthcare facilities). 
Table 7 Reported direct, indirect and total costs

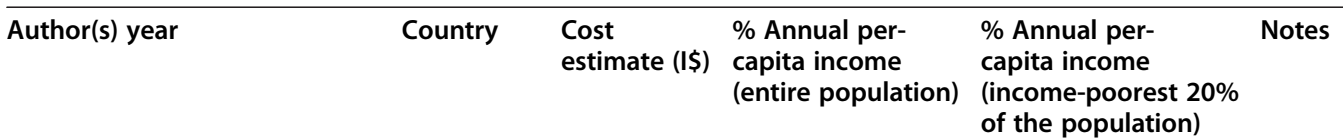

\section{Direct costs}

\begin{tabular}{|c|c|c|c|c|c|}
\hline Aspler, et al. [41] & Zambia & 11 & 2 & 13 & $\begin{array}{l}\text { Total direct costs including medical } \\
\text { and non-medical costs (IQR } 1 \$ 6-1 \$ 17)\end{array}$ \\
\hline Datiko and Lindtjorn [48] & Ethiopia & 17 & 8 & 17 & $\begin{array}{l}\text { Direct patient costs under } \\
\text { community-based DOTS (sd } 1 \$ 12 \text { ) }\end{array}$ \\
\hline Datiko and Lindtjorn [48] & Ethiopia & 49 & 24 & 51 & $\begin{array}{l}\text { Direct patient costs under health } \\
\text { facility-based DOTS (sd } 1 \$ 44 \text { ) }\end{array}$ \\
\hline Kemp, et al. [54] & Malawi & 39 & 21 & $83^{a}$ & $\begin{array}{l}\text { Mean total direct costs for smear- } \\
\text { positive patients (median } \$ \$ 19 \text { ) }\end{array}$ \\
\hline Kemp, et al. [54] & Malawi & 74 & 40 & $156^{a}$ & $\begin{array}{l}\text { Mean total direct costs for smear- } \\
\text { negative patients (median } 1 \$ 38 \text { ) }\end{array}$ \\
\hline Mesfin, et al. [55] & Ethiopia & 114 & 60 & 129 & $\begin{array}{l}\text { Mean total direct costs } \\
\text { (median I\$61; IQR I\$26- I\$132) }\end{array}$ \\
\hline Needham, et al. [57] & Zambia & 64 & 16 & 73 & Total mean direct costs \\
\hline Needham, et al. [58] & Zambia & 14 & 3 & 20 & $\begin{array}{l}\text { Total mean direct medical costs } \\
\text { (median } 1 \$ 5 \text { ) }\end{array}$ \\
\hline Needham, et al. [58] & Zambia & 31 & 8 & 45 & $\begin{array}{l}\text { Total mean direct non-medical } \\
\text { costs (median } 1 \$ 14 \text { ) }\end{array}$ \\
\hline Vassall, et al. [65] & Ethiopia & 527 & 277 & 595 & $\begin{array}{l}\text { Total mean direct pretreatment } \\
\text { costs including transport and non- } \\
\text { transport costs for (median } 1 \$ 66 \text { ) }\end{array}$ \\
\hline Wandwalo, et al. [66] & Tanzania & 59 & 17 & $33^{b}$ & $\begin{array}{l}\text { Total direct costs under a health } \\
\text { facility-based DOTS strategy }\end{array}$ \\
\hline Wandwalo, et al. [66] & Tanzania & 13 & 4 & $8^{b}$ & $\begin{array}{l}\text { Total direct costs under a } \\
\text { community-based DOTS strategy }\end{array}$ \\
\hline \multicolumn{6}{|l|}{ Indirect Costs } \\
\hline Aspler, et al. [41] & Zambia & 21 & 5 & 25 & $\begin{array}{l}\text { Median total indirect costs } \\
(\text { IQR I\$11- I\$39) }\end{array}$ \\
\hline Datiko and Lindtjorn [48] & Ethiopia & 18 & 9 & 18 & $\begin{array}{l}\text { Mean indirect cost under } \\
\text { community-based DOTS }\end{array}$ \\
\hline Datiko and Lindtjorn [48] & Ethiopia & 48 & 50 & 24 & $\begin{array}{l}\text { Mean indirect cost under health } \\
\text { facility-based DOTS }\end{array}$ \\
\hline Mesfin, et al. [55] & Ethiopia & 145 & 76 & 164 & $\begin{array}{l}\text { Average indirect costs from first } \\
\text { consultation to diagnosis including } \\
\text { income lost and travel time cost } \\
\text { (median I\$44; IQR I\$15- } \$ \text { 101) }\end{array}$ \\
\hline Mesfin, et al. [55] & Ethiopia & 54 & 28 & 60 & $\begin{array}{l}\text { Average indirect costs prior to } \\
\text { diagnosis (median } 1 \$ 26 .) \text { including } \\
\text { income last and travel time cost }\end{array}$ \\
\hline Needham, et al. [58] & Zambia & 99 & 25 & 145 & Total lost income (median $\$ \$ 37$ ) \\
\hline Vassall, et al. [65] & Ethiopia & 44 & 23 & 50 & $\begin{array}{l}\text { Total mean indirect pretreatment } \\
\text { costs (median } 1 \$ 0 \text { ) }\end{array}$ \\
\hline Wandwalo, et al. [66] & Tanzania & 56 & 16 & $32^{b}$ & $\begin{array}{l}\text { Total indirect costs under a health } \\
\text { facility-based DOTS strategy }\end{array}$ \\
\hline Wandwalo, et al. [66] & Tanzania & 19 & 5 & $11^{\mathrm{b}}$ & $\begin{array}{l}\text { Total indirect costs under a } \\
\text { community-based DOTS strategy }\end{array}$ \\
\hline \multicolumn{6}{|l|}{ Total Costs } \\
\hline Aspler, et al. [41] & Zambia & 34 & 7 & 41 & $\begin{array}{l}\text { Total median costs per patients (IQR } \\
1 \$ 19-1 \$ 56) \text { in which direct and } \\
\text { indirect costs comprised } 34 \% \text { and } \\
62 \% \text {, respecitvely }\end{array}$ \\
\hline
\end{tabular}


Table 7 Reported direct, indirect and total costs (Continued)

\begin{tabular}{|c|c|c|c|c|c|}
\hline Chard, S. [46] & Uganda & 25 & 8 & $27^{c}$ & $\begin{array}{l}\text { Total reported costs for biomedical } \\
\text { treatment }\end{array}$ \\
\hline Datiko and Lindtjorn [48] & Ethiopia & 34 & 17 & $36^{\mathrm{d}}$ & $\begin{array}{l}\text { Total patient costs under } \\
\text { community-based DOTS (sd I\$16) }\end{array}$ \\
\hline Datiko and Lindtjorn [48] & Ethiopia & 99 & 48 & $104^{d}$ & $\begin{array}{l}\text { Total patient costs under health } \\
\text { facility-based DOTS (sd } 1 \$ 50)\end{array}$ \\
\hline Floyd, et al. [51] & South Africa & 155 & 4 & $23^{\mathrm{e}}$ & Total cost to patients under DOTS \\
\hline Floyd, et al. [51] & South Africa & 461 & 12 & $67^{e}$ & $\begin{array}{l}\text { Total cost to patients under the } \\
\text { conventional system }^{f}\end{array}$ \\
\hline Gibson and Boillot [52] & Sierra Leone & 26 & 10 & $33^{9}$ & $\begin{array}{l}\text { Total cost for patients under the } \\
\text { National Leprosy and TB Control } \\
\text { Program }\end{array}$ \\
\hline Mesfin, et al. [55] & Ethiopia & 259 & 136 & 292 & $\begin{array}{l}\text { Mean total costs (median } 1 \$ 119 ; \\
\text { IQR I\$53- I\$242) }\end{array}$ \\
\hline Needham, et al. [58] & Zambia & 68 & 17 & 100 & Total patient costs (median I\$32) \\
\hline Saunderson, P.R. [31] & Uganda & 584 & 249 & 809 & $\begin{array}{l}\text { Total cost under the strategy that } \\
\text { utilizes hospitalization for the first } \\
\text { two months of treatment followed } \\
\text { by an outpatient continuation phase } \\
\text { for } 4-10 \text { months. }\end{array}$ \\
\hline Sinanovic and Kumaranayake [64] & South Africa & 102 & 3 & $17^{h}$ & $\begin{array}{l}\text { Total cost per patient attending a } \\
\text { public-non-governmental } \\
\text { organization partnership site } \\
\text { (95\% CI } \$ 73-1 \$ 123)\end{array}$ \\
\hline Sinanovic and Kumaranayake [64] & South Africa & 95 & 2 & $16^{h}$ & $\begin{array}{l}\text { Total cost per patient attending a } \\
\text { public-non-governmental } \\
\text { organization partnership site } \\
(95 \% \mathrm{Cl} \text { I\$82- } 104)\end{array}$ \\
\hline Sinanovic and Kumaranayake [64] & South Africa & 264 & 7 & $44^{h}$ & $\begin{array}{l}\text { Total cost per patient attending a } \\
\text { public hospital (95\% Cl I\$251- I\$274) }\end{array}$ \\
\hline Sinanovic and Kumaranayake [64] & South Africa & 317 & 8 & $53^{h}$ & $\begin{array}{l}\text { Total cost per patient attending a } \\
\text { public hospital (95\% Cl I\$293- } \$ 363 \text { ) }\end{array}$ \\
\hline Sinanovic, et al. [63] & South Africa & 2 & 0.044 & $0.24^{i}$ & $\begin{array}{l}\text { Total cost for a clinic DOTS visit, where } \\
\text { clinic used for DOTS and total cost } \\
\text { for monitoring/collection of drugs } \\
\text { in Nyanga ( } 95 \% \text { CI I\$1- } \$ 2 \text { ) }\end{array}$ \\
\hline Sinanovic, et al. [63] & South Africa & 2 & 0.041 & $0.23^{i}$ & $\begin{array}{l}\text { Total cost for a clinic DOTS visit, where } \\
\text { clinic used for DOTS and total cost } \\
\text { for monitoring/collection of drugs } \\
\text { in Guguletu ( } 95 \% \text { CI I\$1- I\$2) }\end{array}$ \\
\hline Sinanovic, et al. [63] & South Africa & 1 & 0.01 & $0.08^{i}$ & $\begin{array}{l}\text { Total cost for a DOTS visit, where } \\
\text { community treatment supporter u } \\
\text { used for in Guguletu ( } 95 \% \mathrm{Cl}|\$ 1-| \$ 2)\end{array}$ \\
\hline Vassall, et al. [65] & Ethiopia & 567 & 298 & 639 & Total mean pretreatment costs \\
\hline Wandwalo, et al. [66] & Tanzania & 116 & 32 & $65^{\mathrm{b}}$ & $\begin{array}{l}\text { Total costs under a health facility- } \\
\text { based DOTS strategy }\end{array}$ \\
\hline Wandwalo, et al. [66] & Tanzania & 32 & 9 & $18^{\mathrm{b}}$ & $\begin{array}{l}\text { Total costs under a community- } \\
\text { based DOTS strategy }\end{array}$ \\
\hline Wilkinson, et al. [67] & South Africa & 183 & 5 & $27^{j}$ & $\begin{array}{l}\text { Total costs for patients treated under } \\
\text { community-based DOTS strategy. }\end{array}$ \\
\hline
\end{tabular}

${ }^{a}$ Income share based on 1998 estimates instead of 2000; ${ }^{b}$ Income share based on 2000 estimates instead of $2005 ;{ }^{c}$ Income share based on 1999 estimates instead of 1998; ${ }^{d}$ Income share based on 2005 estimates instead of 2006; ${ }^{\mathrm{e}}$ Income share based on 1995 estimates instead of $1996 ;{ }^{f}$ The conventional system hospitalizes patients for the first two months of treatment; ${ }^{9}$ Income share assumed to be $6 \%$ by authors in absence of World Bank data; ${ }^{\mathrm{h}}$ Income share based on 2000 estimates instead of $2001 ;{ }^{i}$ Income share based on 1995 estimates instead of $1997 ;{ }^{j}$ Income share based on 1995 estimates instead of $1996 ;{ }^{k}$ Income share based on 2000 estimates instead of 1996. 
Table 8 Types of catastrophic costs

\begin{tabular}{|c|c|c|c|c|c|}
\hline Author(s) (year) & Country & $\begin{array}{l}\text { Catastrophic Costs for Average } \\
\text { Income Earners }\end{array}$ & $\begin{array}{l}\text { Range (\% of } \\
\text { annual income) }\end{array}$ & Catastrophic Costs for Lowest $20 \%$ & $\begin{array}{l}\text { Range (\% of } \\
\text { annual income) }\end{array}$ \\
\hline Aspler, et al. (1998) [41] & Zambia & Total & 12 & $\begin{array}{l}\text { Total, direct, indirect, pre-diagnosis, treatment, } \\
\text { time, transportation, medication, hospitalization, } \\
\text { direct clinic-based DOTS, indirect clinic-based } \\
\text { DOTS }\end{array}$ & $12-40$ \\
\hline Awofeso, N. (1998) [42] & Nigeria & Medication & 121 & Medication & 589 \\
\hline Bevan, E. (1997) [43] & Kenya & - & - & Medication, syringes and needles & $11-32$ \\
\hline Chard, S. (2001) [46] & Uganda & $\begin{array}{l}\text { Medication, traditional healer, } \\
\text { "tipping" providers }\end{array}$ & $12-165$ & Medication, traditional healer, "tipping" providers & $41-544$ \\
\hline Chard, S. (2009) [47] & Uganda & Private provider, traditional healer & $47-188$ & Private provider, traditional healer & $154-618$ \\
\hline Datiko and Lindtjørn (2010) [48] & Ethiopia & Total, travel, time, caregiver, direct, food & $17-48$ & Total, travel, time, caregiver, direct, food & $15-104$ \\
\hline Floyd, et al. (2003) [50] & Malawi & Travel, hospitalization, DOTS visit & $13-262$ & Travel, hospitalization & 18-1043 \\
\hline Floyd, et al. (1997) [51] & South Africa & Total, hospitalization & $11-12$ & Total, hospitalization & $17-67$ \\
\hline Gibson, et al. (1998) [52] & Sierra Leone & $\begin{array}{l}\text { pre-program, program, hospital } \\
\text { admission fees }\end{array}$ & $17-88$ & $\begin{array}{l}\text { Total, pre-program, program, hospital } \\
\text { admission fees }\end{array}$ & $32-287$ \\
\hline Harper, et al. (2003) [53] & The Gambia & Private treatment & 11 & Private treatment & 54 \\
\hline Kemp, et al. (2007) [54] & Malawi & $\begin{array}{l}\text { Direct, income lost, user fees and } \\
\text { medication, pre-diagnosis }\end{array}$ & $21-40$ & $\begin{array}{l}\text { Direct, income lost, user fees and medication, } \\
\text { pre-diagnosis, food, travel }\end{array}$ & $15-155$ \\
\hline Mesfin, et al. (2010) [55] & Ethiopia & $\begin{array}{l}\text { Medical, non-medical, indirect, direct, } \\
\text { medication, caregiver, total }\end{array}$ & $11-136$ & $\begin{array}{l}\text { Medical, non-medical, indirect, direct, } \\
\text { medication, caregiver, travel, total }\end{array}$ & $12-292$ \\
\hline Moalosi, et al. (2003) [56] & Botswana & $\begin{array}{l}\text { Total caregiver costs Caregiver } \\
\text { hospitalization Caregiver food and supplies }\end{array}$ & $13-51$ & $\begin{array}{l}\text { Total caregiver costs, caregiver } \\
\text { hospitalization, caregiver medication, } \\
\text { caregiver food and supplies }\end{array}$ & $29-258$ \\
\hline Needham, et al. (1996) [57] & Zambia & Total medical, direct, income lost & $16-148$ & $\begin{array}{l}\text { Total medical, total non-medical, direct, } \\
\text { income lost }\end{array}$ & $43-688$ \\
\hline Needham, et al. (1998) [58] & Zambia & $\begin{array}{l}\text { Total, indirect, pre-diagnosis, non-medical, } \\
\text { food }\end{array}$ & $11-47$ & $\begin{array}{l}\text { Total, indirect, pre-diagnosis, non-medical, } \\
\text { medical, food, diagnostic tests, caregiver, } \\
\text { private provider, traditional healer, consultation } \\
\text { fees, travel, }\end{array}$ & $15-214$ \\
\hline Needham, et al. (2004) [59] & Zambia & - & - & Transportation & 11 \\
\hline Nganda, et al. (2003) [60] & Kenya & Hospitalization, travel & 33-101 & Hospitalization, travel & $22-336$ \\
\hline Okello, et al. (2003) [61] & Uganda & Hospitalization, travel & $12-73$ & Hospitalization, travel & $40-241$ \\
\hline Saunderson, P.R. (1995) [31] & Uganda & Total, hospitalization, pre-diagnosis, indirect & $34-249$ & Total, hospitalization, pre-diagnosis, indirect & $111-809$ \\
\hline Sinanovic, et al. (2003) [63] & South Africa & - & - & Total & $11-43$ \\
\hline Sinanovic and Kumaranay-ake (2006) [64] & South Africa & - & - & Total, time, travel & $11-53$ \\
\hline Vassall, et al. (2010) [65] & Ethiopia & Direct, indirect, travel and total pretreatment & $23-298$ & $\begin{array}{l}\text { Direct, indirect, travel and total } \\
\text { pretreatment }\end{array}$ & $50-639$ \\
\hline Wandwalo, et al. (2005) [66] & Tanzania & Total, direct, indirect & $16-32$ & Total, direct, indirect & $18-65$ \\
\hline Wilkinson, et al. (1997) [67] & South Africa & - & - & Total, hospitalization & $20-27$ \\
\hline Wyss, et al. (2001) [68] & Tanzania & Private provider & 12 & Traditional healer, private provider, hospitalization & $10-29$ \\
\hline
\end{tabular}


Finally, since we find that patients in some countries spend substantial amounts of money for TB treatment and care in the private sector despite public-sector $\mathrm{TB}$ programs that offer some services free of charge, interventions to decrease the demand for private-sector $\mathrm{TB}$ treatment and care could reduce the financial burden to TB patients. Such interventions could improve media campaigns to ensure that patients are aware of where and when they can access public-sector TB treatment and health sector reforms leading to increased quality of care in the public sector. Rigorous evaluation studies, accompanying the implementation of such interventions, will contribute to our understanding of their performance and impact on patient healthcare expenditures and population health outcomes.

\section{Limitations}

There are several limitations of this review: First, we included studies that were conducted from 1994 to present. Earlier studies might not be generalizable to current strategies because TB control program policies may have changed since their publication. Second, although no official criteria exist for assessing studies on patient costs, other systematic reviews of patient costs have used various quality assessment criteria for evaluating study quality [23,77-79]. Due to our broader study inclusion criteria, we were unable to adopt similar formal criteria for evaluating study quality beyond ensuring that studies had clearly defined objectives, clearly defined study populations, and a quantitative measure of patient-costs. This limitation may have led to a relatively higher weight placed on results from "low quality" studies in the interpretation and discussion of the summary findings from our systematic review than would have been the case if we could have more clearly distinguished between "low" and "high quality" studies.

Third, many studies assessed only a few specific types of costs, so comparing total cost burden to patients across studies is difficult and may be underestimated. Similarly, the studies that reported aggregate direct and indirect costs might have defined direct and indirect costs differently, so these reported measures might not be comparable. Additionally, since costs were measured differently and may reflect different time periods, (for instance some travel costs were measured as one-time costs, and others were measured over the entire course of treatment), comparing these cost burdens on patients' average annual or monthly income are difficult and must be interpreted with caution.

Moreover, only five studies directly surveyed patients on their incomes. In our estimation of the impact of TB patient costs on patients' economic circumstances, we thus had to rely on national income estimates. However, it is very likely that TB patients' average income deviates substantially from the national average, so that our relative measures of the out-of-pocket cost burden to patients and households may be biased.

Furthermore, since data on income shares of the income-poorest $20 \%$ of the population were missing for several country-years, we used estimates from the closest years for which data were available for a country, but this could potentially yield inaccurate estimates of per capita GDP for this portion of the population. Finally, evidence on TB patient costs was only available for 11 out of 47 countries in sub-Saharan Africa. Results from these studies cannot be extrapolated to the rest of the continent, and it is possible that patients in other parts of Africa might incur lower TB patient costs.

\section{Conclusion}

Tuberculosis can place considerable financial and economic burden on patients and households in sub-Saharan Africa. Here, we identified 30 relevant studies investigating TB patient costs in sub-Saharan Africa before, during and after diagnosis and treatment for TB. We found that patient costs vary considerably both by total amounts and according to the different types of costs incurred by patients in DOTS and non-DOTS settings. In many settings, patient costs were found to be "catastrophic" in that they amounted to $10 \%$ or more of average annual incomes. These costs have the potential to financially strain patients and their households, leading to detrimental effects such as delayed care seeking and increased default rates of TB patients, potentially fueling the spread of $\mathrm{TB}$ or increasing multi-drug resistant TB in sub-Saharan Africa. Future research needs to assess which interventions and health systems reforms are most effective and cost-effective in reducing the financial burdens that patients incur when seeking TB treatment and care.

\section{Additional file}

Additional file 1: Systematic review search algorithm.

\section{Competing interests}

The authors declare that they have no competing interests.

\section{Authors' contributions}

DB designed the study, conducted the search, extracted and interpreted data, and wrote the manuscript. SA served as a second reviewer for article inclusion and exclusion, extracted data and assisted with the manuscript. TB and $\mathrm{MB}$ supervised the study and contributed to study design, methodologies, interpreted results, and assisted with writing the final manuscript. All authors read and approved the final manuscript.

\section{Acknowledgements}

The authors would like to acknowledge Julie Whelan at the Countway Library of Medicine and Joshua Salomon in the Department of Global Health and Population at Harvard School of Public Health for their valuable contributions. 


\section{Author details}

${ }^{1}$ Department of Global Health and Population, Harvard School of Public Health, 677 Huntington Avenue, Boston, MA 02115, USA. ²Department of Epidemiology, Harvard School of Public Health, 677 Huntington Avenue, Boston, MA 02115, USA. ${ }^{3}$ Africa Centre for Health and Population Studies, University of KwaZulu-Natal, KwaZulu-Natal, Mtubatuba, South Africa.

\section{Received: 15 April 2012 Accepted: 22 October 2012}

Published: 14 November 2012

\section{References}

1. World Health Organization: Global Tuberculosis Control 2010. Geneva: World Health Organization; 2010.

2. Lonnroth K, Jaramillo E, Williams BG, Dye C, Raviglione M: Drivers of tuberculosis epidemics: The role of risk factors and social determinants. Soc Sci Med 2009, 68:2240-2246.

3. Hoa NB, Tiemersma EW, Sy DN, Nhung NV, Gebhard A, Borgdorff MW, Cobelens FG: Household expenditure and tuberculosis prevalence in VietNam: prediction by a set of household indicators. Int J Tuberc Lung Dis 2011, 15(1):32-37.

4. Muniyandi M, Ramachandran R: Socioeconomic inequalities of tuberculosis in India. Expert Opin Pharmacother 2008, 9(10):1623-1628.

5. Siddiqi K, Barnes H, Williams R: Tuberculosis and poverty in the ethnic minority population of West Yorkshire: an ecological study. Commun Dis Public Health 2001, 4(4):242-246.

6. Spence DP, Hotchkiss J, Williams CS, Davies PD: Tuberculosis and poverty. BMJ 1993, 307(6907):759-761.

7. Holtgrave DR, Crosby RA: Social determinants of tuberculosis case rates in the United States. Am J Prev Med 2004, 26(2):159-162.

8. World Health Organization: Addressing poverty in TB control: Options for national TB control programems. Geneva: World Health Organization; 2005.

9. Fabricant SJ, Kamara CW, Mills A: Why the poor pay more: Household curative expenditures in rural Sierra Leone. Int J Health Plann Manage 1999, 14:179-199.

10. Elender F, Bentham G, Langford I: Tuberculosis mortality in England and Wales during 1982-1992: its association with poverty, ethnicity and AIDS. Soc Sci Med 1998, 46(6):673-681.

11. Hansel NN, Wu AW, Chang B, Diette GB: Quality of life in tuberculosis: patient and provider perspectives. Quality of life research: an international journal of quality of life aspects of treatment, care and rehabilitation 2004, 13(3):639-652

12. Paton $\mathrm{NI}, \mathrm{Ng}$ YM: Body composition studies in patients with wasting associated with tuberculosis. Nutrition (Burbank, Los Angeles County, Calif) 2006, 22(3):245-251.

13. Sagbakken M, Frich JC, Bjune G: Barriers and enablers in the management of tuberculosis treatment in Addis Ababa, Ethiopia: a qualitative study. BMC Public Health 2008, 8:11.

14. Lonnroth K, Castro KG, Chakaya JM, Chauhan LS, Floyd K, Glaziou P, Raviglione MC: Tuberculosis control and elimination 2010-50: cure, care, and social development. Lancet 2010, 375(9728):1814-1829.

15. Organization WH: Involving Private Practitioners in Tuberculosis Control: Issues, Interventions, and Emerging Policy Framework. Geneva: World Health Organization; 2001.

16. Chang B, Wu AW, Hansel NN, Diette GB: Quality of life in tuberculosis: A review of English language literature. Qual Life Res 2004, 13:1633-1642.

17. Ahlburg DA: The economic impacts of tuberculosis. In Ministerial Conference. Amsterdam: The Stop TB Initative of the World Health Organization; 2000.

18. Russell S: The economic burden of illness for households in developing countries: A review of studies focusing on malaria, tuberculosis, and human immunodeficiency virus/acqiured immunodeficiency syndrome. American Journal of Tropical Medicine and Hygeine 2004, 71(Suppl 2):147-155.

19. Mclntyre D, Thiede M, Dahlgren G, Whitehead M: What are the economic consequences for households of illness and of paying for health care in low- and middle-income country contexts? Soc Sci Med 2006 62(4):858-865.

20. Leive $A, X u K$ : Coping with out-of-pocket health payments: empirical evidence from 15 African countries. Bull World Health Organ 2008, 86(11):849-856.
21. Chimbindi N, Bärnighausen T, Newell M: Time and money: the costs of utilizing HIV and TB treatment in rural KwaZulu-Natal. Washington, D.C: AIDS 2012; 2012.

22. World Health Organization: 10 Facts on health financing. Geneva: World Health Organization; 2010.

23. Ukwaja KN, Modebe O, Igwenyi C, Alobu I: The economic burden of tuberculosis care for patients and households in Africa: a systematic review. Int J Tuberc Lung Dis 2012, 16(6):733-739.

24. Rajeswari R, Balasubramanian R, Muniyandi M, Geetharamani S, Thresa X, Venkatesan P: Socio-economic impact of tuberculosis on patients and family in India. Int J Tuberc Lung Dis 1999, 3(10):869-877.

25. Jackson S, Sleigh AC, Wang GJ, Liu XL: Poverty and the economic effects of TB in rural China. Int J Tuberc Lung Dis 2006, 10(10):1104-1110.

26. Pizzi LT, Lofland JH: Economic Evaluation in U.S. Health Care: Principles and Applications. Sudbury: Jones and Bartlett Publishers; 2006.

27. Raviglione M: The TB epidemic from 1992 to 2002. Tuberculosis 2003, 83:4-14

28. Liberati A, Altman DG, Tetzlaff J, Mulrow C, Gotzsche PC, loannidis JP, Clarke M, Devereaux PJ, Kleijnen J, Moher D: The PRISMA statement for reporting systematic reviews and meta-analyses of studies that evaluate health care interventions: explanation and elaboration. PLoS Med 2009, 6(7):e1000100

29. OANDS currency converter: Accessed April 3, 2011. Available at: http://www. oanda.com/

30. Steen TW, Masonde GN: Ngaka ya setswana, ngaka ya sekgoa or both? Health seeking behaviour in Batswana with pulmonary tuberculosis. Soc Sci Med 1999, 48(2):163-172.

31. Saunderson PR: An economic evaluation of alternative programme designs for tuberculosis control in rural Uganda. Soc Sci Med 1995, 40(9):1203-1212.

32. Inflation, average consumer prices. http://www.imf.org/external/pubs/ft/weo/ 2009/02/weodata/weoselgr.aspx.

33. World Development Indicators: World Development Indicators. http://data worldbank.org/data-catalog/world-development-indicators.

34. Castillo-Riquelme M, Mclntyre D, Barnes K: Household burden of malaria in South Africa and Mozambique: is there a catastrophic impact? Trop Med Int Health 2008, 13(1):108-122.

35. Limwattananon S, Tangcharoensathien V, Prakongsai P: Catastrophic and poverty impacts of health payments: results from national household surveys in Thailand. Bull World Health Organ 2007, 85(8):600-606.

36. Pradhan $M$, Prescott $N$ : Social risk management options for medical care in Indonesia. Health Econ 2002, 11(5):431-446.

37. Ranson MK: Reduction of catastrophic health care expenditures by a community-based health insurance scheme in Gujarat, India: current experiences and challenges. Bull World Health Organ 2002, 80(8):613-621.

38. Claessens NJ, Gausi FF, Meijnen S, Weismuller MM, Salaniponi FM, Harries AD: High frequency of tuberculosis in households of index TB patients. Int J Tuberc Lung Dis 2002, 6(3):266-269.

39. Rathi SK, Akhtar S, Rahbar MH, Azam SI: Prevalence and risk factors associated with tuberculin skin test positivity among household contacts of smear-positive pulnionary tuberculosis cases in Umerkot, Pakistan. Int J Tuberc Lung Dis 2002, 6(10):851-857.

40. Wang PD, Lin RS: Tuberculosis transmission in the family. J Infect 2000, 41(3):249-251

41. Aspler A, Menzies D, Oxlade O, Banda J, Mwenge L, Godfrey-Faussett $\mathrm{P}$, Ayles $\mathrm{H}$ : Cost of tuberculosis diagnosis and treatment from the patient perspective in Lusaka, Zambia. Int J Tuberc Lung Dis 2008, 12(8):928-935.

42. Awofeso N: Implementing tuberculosis control programmes in Kaduna State, Nigeria. Int J Tuberc Lung Dis 1998, 2(4):336-337.

43. Bevan E: Tuberculosis treatment is expensive for patients in developing countries. BMJ 1997, 315(7101):187-188.

44. Brouwer JA, Boeree MJ, Kager P, Varkevisser CM, Harries AD: Traditional healers and pulmonary tuberculosis in Malawi. Int J Tuberc Lung Dis 1998 , 2(3):231-234.

45. Cambanis A, Yassin MA, Ramsay A, Squire SB, Arbide I, Cuevas LE: Rural poverty and delayed presentation to tuberculosis services in Ethiopia. Trop Med Int Health 2005, 10(4):330-335. 
46. Chard SE: Ugandan women's health beliefs, social networks and tuberculosis treatment-seeking. 3036337. United States - Ohio: Case Western Reserve University; 2001.

47. Chard SE: Routes to Government TB Treatment: Private Providers, Family Support, and the Process of TB Treatment Seeking among Ugandan Women. Medical Anthropology Quarterly (New Series) 2009, 23(3):257-276

48. Datiko DG, Lindtjorn B: Cost and cost-effectiveness of treating smear-positive tuberculosis by health extension workers in Ethiopia: An ancillary cost-effectiveness analysis of community randomized trial. PLoS One 2010, 5:2

49. Edginton ME, Sekatane CS, Goldstein SJ: Patients' beliefs: do they affect tuberculosis control? A study in a rural district of South Africa. Int $J$ Tuberc Lung Dis 2002, 6(12):1075-1082

50. Floyd K, Skeva J, Nyirenda T, Gausi F, Salaniponi F: Cost and cost-effectiveness of increased community and primary care facility involvement in tuberculosis care in Lilongwe District, Malawi. Int J Tuberc Lung Dis 2003, 7(9 SUPPL. 1):S29-S37.

51. Floyd K, Wilkinson D, Gilks C: Comparison of cost effectiveness of directly observed treatment (DOT) and conventionally delivered treatment for tuberculosis: experience from rural South Africa. BMJ 1997, 315(7120):1407-1411.

52. Gibson N, Boillot F, Jalloh $\mathrm{H}$ : The cost of tuberculosis to patients in Sierra Leone's war zone. Int J Tuberc Lung Dis 1998, 2(9):726-731.

53. Harper M, Ahmadu FA, Ogden JA, McAdam KP, Lienhardt C: Identifying the determinants of tuberculosis control in resource-poor countries: insights from a qualitative study in The Gambia. Trans R Soc Trop Med Hyg 2003, 97(5):506-510.

54. Kemp JR, Mann G, Simwaka BN, Salaniponi FM, Squire SB: Can Malawi's poor afford free tuberculosis services? Patient and household costs associated with a tuberculosis diagnosis in Lilongwe. Bull World Health Organ 2007, 85(8):580-585.

55. Mesfin MM, Newell JN, Madeley RJ, Mirzoev TN, Tareke IG, Kifle YT, Gessessew A, Walley JD: Cost implications of delays to tuberculosis diagnosis among pulmonary tuberculosis patients in Ethiopia. BMC Public Health 2010, 10

56. Moalosi G, Floyd K, Phatshwane J, Moeti T, Binkin N, Kenyon T: Cost-effectiveness of home-based care versus hospital care for chronically ill tuberculosis patients, Francistown, Botswana. Int J Tuberc Lung Dis 2003, 7(9 SUPPL. 1):S80-S85.

57. Needham DM, Godfrey-Faussett P: Economic barriers for tuberculosis patients in Zambia. Lancet 1996, 348(9020):134-135.

58. Needham DM, Godfrey-Faussett P, Foster SD: Barriers to tuberculosis control in urban Zambia: the economic impact and burden on patients prior to diagnosis. Int J Tuberc Lung Dis 1998, 2(10):811-817.

59. Needham DM, Bowman D, Foster SD, Godfrey-Faussett P: Patient care seeking barriers and tuberculosis programme reform: a qualitative study. Health Policy 2004, 67(1):93-106

60. Nganda B, Wang'Ombe J, Floyd K, Kangangi J: Cost and cost-effectiveness of increased community and primary care facility involvement in tuberculosis care in Machakos District, Kenya. Int J Tuberc Lung Dis 2003, 7(9 SUPPL. 1):S14-S20.

61. Okello D, Floyd K, Adatu F, Odeke R, Gargioni G: Cost and costeffectiveness of community-based care for tuberculosis patients in rural Uganda. Int J Tuberc Lung Dis 2003, 7(9 Suppl 1):S72-S79.

62. Pocock D, Khare A, Harries AD: Case holding for tuberculosis in Africa: the patients' perspective. Lancet 1996, 347:1258.

63. Sinanovic E, Floyd K, Dudley L, Azevedo V, Grant R, Maher D: Cost and cost-effectiveness of community-based care for tuberculosis in Cape Town, South Africa. Int J Tuberc Lung Dis 2003, 7(9 SUPPL. 1):S56-S62.

64. Sinanovic E, Kumaranayake L: Financing and cost-effectiveness analysis of public-private partnerships: Provision of tuberculosis treatment of South Africa. Cost Effectiveness and Resource Allocation 2006, 4.

65. Vassall A, Seme A, Compernolle P, Meheus F: Patient costs of accessing collaborative tuberculosis and human immunodefi ciency virus interventions in Ethiopia. Int J Tuberc Lung Dis 2010, 14(5):604-610.

66. Wandwalo E, Robberstad B, Morkve O: Cost and cost-effectiveness of community based and health facility based directly observed treatment of tuberculosis in Dar es Salaam, Tanzania. Cost Effectiveness and Resource Allocation 2005, 3
67. Wilkinson D, Floyd K, Gilks CF: Costs and cost-effectiveness of alternative tuberculosis management strategies in South Africa - Implications for policy. South African Medical Journal 1997, 87(4):451-455.

68. Wyss K, Kilima P, Lorenz N: Costs of tuberculosis for households and health care providers in Dar es Salaam, Tanzania. Trop Med Int Health 2001, 6(1):60-68.

69. Floyd K: Costs and effectiveness-the impact of economic studies on TB control. Tuberculosis (Edinb) 2003, 83(1-3):187-200.

70. World Health Organization: Towards universal access: Scaling up priority HIV/ AIDS interventions in the health sector. Geneva: World Health Organization; 2010.

71. Vassall A, Compernolle P: Estimating the resource needs of scaling-up HIV/AIDS and tuberculosis interventions in sub-Saharan Africa: a systematic review for national policy makers and planners. Health policy (Amsterdam, Netherlands) 2006, 79(1):1-15.

72. Beauliere A, Toure S, Alexandre PK, Kone K, Pouhe A, Kouadio B, Journy N, Son J, Ettiegne-Traore $V$, Dabis $F$, et al: The financial burden of morbidity in HIV-infected adults on antiretroviral therapy in Cote d'Ivoire. PLoS One 2010, 5(6):e11213.

73. Boyer S, Marcellin F, Ongolo-Zogo P, Abega SC, Nantchouang R, Spire B, Moatti JP: Financial barriers to HIV treatment in Yaounde, Cameroon: first results of a national cross-sectional survey. Bull World Health Organ 2009, 87(4):279-287.

74. Mugisha F, Kouyate B, Gbangou A, Sauerborn R: Examining out-of-pocket expenditure on health care in Nouna, Burkina Faso: implications for health policy. Trop Med Int Health 2002, 7(2):187-196.

75. Ettling M, McFarland DA, Schultz LJ, Chitsulo L: Economic impact of malaria in Malawian households. Trop Med Parasitol 1994, 45(1):74-79.

76. Deressa W, Hailemariam D, Ali A: Economic costs of epidemic malaria to households in rural Ethiopia. Trop Med Int Health 2007, 12(10):1148-1156.

77. Zhu TY, Tam LS, Li EK: Cost-of-illness studies in systemic lupus erythematosus: A systematic review. Arthritis Care Res 2011, 63(5):751-760

78. Bahadori K, Doyle-Waters MM, Marra C, Lynd L, Alasaly K, Swiston J, FitzGerald JM: Economic burden of asthma: a systematic review. BMC Pulm Med 2009, 9:24.

79. Cooper NJ: Economic burden of rheumatoid arthritis: a systematic review. Rheumatology (Oxford) 2000, 39(1):28-33.

doi:10.1186/1471-2458-12-980

Cite this article as: Barter et al:: Tuberculosis and poverty: the contribution of patient costs in sub-Saharan Africa - a systematic review. BMC Public Health 2012 12:980.

\section{Submit your next manuscript to BioMed Central and take full advantage of:}

- Convenient online submission

- Thorough peer review

- No space constraints or color figure charges

- Immediate publication on acceptance

- Inclusion in PubMed, CAS, Scopus and Google Scholar

- Research which is freely available for redistribution 